\title{
Heterogeneous atmospheric bromine chemistry
}

\author{
D. J. Lary and M. P. Chipperfield \\ Centre for Atmospheric Science, Cambridge University, Cambridge, England \\ R. Toumi \\ Department of Physics, Imperial College, London, England \\ T. Lenton \\ Centre for Atmospheric Science, Cambridge University, Cambridge, England
}

\begin{abstract}
This paper considers the effect of heterogeneous bromine reactions on stratospheric photochemistry. We have considered reactions on both sulfate aerosols and on polar stratospheric clouds (PSCs). It is shown that the hydrolysis of $\mathrm{BrONO}_{2}$ on sulfate aerosols enhances the $\mathrm{HOBr}$ concentration, which in turn enhances the $\mathrm{OH}$ and $\mathrm{HO}_{2}$ concentrations, thereby reducing the $\mathrm{HCl}$ lifetime and concentration. The hydrolysis of $\mathrm{BrONO}_{2}$ leads to a nighttime production of $\mathrm{HOBr}$, making $\mathrm{HOBr}$ a major nighttime bromine reservoir. The photolysis of $\mathrm{HOBr}$ gives a rapid increase in the $\mathrm{OH}$ and $\mathrm{HO}_{2}$ concentration at dawn, as was recently observed by Salawitch et al. [1994]. The increase in the $\mathrm{OH}$ and $\mathrm{HO}_{2}$ concentration, and the decrease in the $\mathrm{HCl}$ concentration, leads to additional ozone depletion at all latitudes and for all season. At temperatures below $210 \mathrm{~K}$ the bulk phase reaction of $\mathrm{HOBr}$ with $\mathrm{HCl}$ in sulfate aerosols becomes important. The most important heterogeneous bromine reactions on polar stratospheric clouds are the mixed halogen reactions of $\mathrm{HCl}$ with $\mathrm{HOBr}$ and $\mathrm{BrONO}_{2}$ and of $\mathrm{HBr}$ with $\mathrm{HOCl}$ and $\mathrm{ClONO}_{2}$.
\end{abstract}

\section{Introduction}

The recent World Meteorological Organization (WMO) assessment [1992] reported that for the first time there are statistically significant decreases in ozone in all seasons in both the northern and southern hemispheres at middle and high latitudes during the 1980s and that most of this decrease is occurring in the lower stratosphere. This finding has also been supported by trends derived from ozonesondes [Logan, 1994]. This paper shows that at least part of this ozone loss is likely to be due to in situ heterogeneous bromine reactions.

The atmospheric chemistry of reactive bromine species is characterized by their short lifetimes. The longestlived reactive bromine species is $\mathrm{HBr}$, which has a lifetime of up to a day but constitutes only a small fraction of the total reactive bromine $\left(\mathrm{BrO}_{y}\right)$ present in the atmosphere [Lary, 1995]. In contrast, the longest-lived reactive chlorine species is $\mathrm{HCl}$ which typically has a lifetime of over a week in the lower stratosphere and often constitutes the largest fraction of the total reactive chlorine $\left(\mathrm{ClO}_{y}\right)$ present in the atmosphere.

Heterogeneous chlorine reactions are important because they provide a mechanism, not provided by gas

Copyright 1996 by the American Geophysical Union.

Paper number 95JD02839.

0148-0227/96/95JD-02839\$05.00 phase chemistry, for the rapid conversion of $\mathrm{HCl}$ into $\mathrm{ClO}_{x}\left(=\mathrm{Cl}+\mathrm{ClO}+2 \mathrm{Cl}_{2} \mathrm{O}_{2}\right)$. Since the timescale for $\mathrm{HCl}$ production is several days it is only recycled slowly. Therefore, the heterogeneous reactions considerably perturb the chlorine partitioning. In contrast, because bromine species are short-lived heterogeneous bromine reactions are important as they allow the formation of catalytic cycles for the conversion of $\mathrm{H}_{2} \mathrm{O}$ into $\mathrm{HO}_{x}$. $\left(=\mathrm{OH}+\mathrm{HO}_{2}\right), \mathrm{HCl}$ into $\mathrm{ClO}$ and $\mathrm{NO}_{x}\left(=\mathrm{NO}+\mathrm{NO}_{2}\right)$ into $\mathrm{HNO}_{3}$, as well as for the rapid recycling of the bromine reservoir species $\mathrm{BrONO}_{2}$ and $\mathrm{HBr}$. This leads to ozone loss at all latitudes and for all seasons, particularly when high loadings of sulfate aerosol are present in the atmosphere.

\section{Calculation of Heterogeneous Reaction Rates}

Table 1 shows the heterogeneous bromine reactions used in this study. This set of reactions was constructed by analogy with the known heterogeneous chlorine reactions. Recently, reactions (1) and (2) in Table 1 have been studied by Abbatt [1994] on ice. The measured $\gamma$ values are very similar to the value of 0.3 for the reaction $\mathrm{HOCl}$ with $\mathrm{HCl}$ on water ice [Hanson and Ravishankara, 1991; Abbatt and Molina, 1992].

Reactions (1) to (3) in Table 1 have been treated as bulk phase reactions on sulfate aerosols because of 
Table 1. Heterogeneous Bromine Reactions Used in This Study

\begin{tabular}{|c|c|c|c|c|c|c|c|c|c|c|c|c|c|}
\hline \multirow[b]{3}{*}{ (R1) } & & & & & & & & & \multirow{2}{*}{$\begin{array}{l}\Delta \mathrm{H}_{298 \mathrm{~K}} \\
\mathrm{~kJ} / \text { Mole }\end{array}$} & \multirow{2}{*}{$\begin{array}{c}\text { Surface } \\
\text { Type }\end{array}$} & \multicolumn{3}{|c|}{$\gamma$} \\
\hline & & \multicolumn{7}{|c|}{ Reaction } & & & A & I & II \\
\hline & & $\mathrm{HBr}$ & + & HOBr & $\longrightarrow$ & $\mathrm{Br}_{2}$ & + & $\mathrm{H}_{2} \mathrm{O}$ & -95.3 & A,I,II & $\mathcal{B}$ & 0.1 & $0.12^{\dagger}$ \\
\hline (R2) & & $\mathrm{HCl}$ & + & HOBr & $\longrightarrow$ & $\mathrm{BrCl}$ & + & $\mathrm{H}_{2} \mathrm{O}$ & -55.6 & A,I,II & $\mathcal{B}$ & 0.1 & $0.25^{\dagger}$ \\
\hline (R3) & & $\mathrm{HBr}$ & + & $\mathrm{HOCl}$ & $\longrightarrow$ & $\mathrm{BrCl}$ & + & $\mathrm{H}_{2} \mathrm{O}$ & -115.8 & A,I,II & $\mathcal{B}$ & 0.1 & 0.3 \\
\hline (R4) & & $\mathbf{H B r}$ & + & $\mathrm{BrONO}_{2}$ & $\longrightarrow$ & $\mathrm{Br}_{2}$ & + & $\mathrm{HNO}_{3}$ & -118.2 & I,II & & 0.3 & 0.3 \\
\hline (R5) & & $\mathrm{HCl}$ & + & $\mathrm{BrONO}_{2}$ & $\longrightarrow$ & $\mathrm{BrCl}$ & + & $\mathrm{HNO}_{3}$ & -78.5 & I,II & & 0.3 & 0.3 \\
\hline (R6) & & $\mathrm{HBr}$ & + & $\mathrm{ClONO}_{2}$ & $\longrightarrow$ & $\mathrm{BrCl}$ & + & $\mathrm{HNO}_{3}$ & -107.3 & I,II & & 0.3 & 0.3 \\
\hline (R7) & * & $\mathrm{H}_{2} \mathrm{O}$ & + & $\mathrm{BrONO}_{2}$ & $\longrightarrow$ & $\mathrm{HOBr}$ & + & $\mathrm{HNO}_{3}$ & -22.9 & $\mathbf{A}, \mathbf{I}, \mathbf{I I}$ & $0.4^{t}$ & 0.006 & 0.3 \\
\hline (R8) & & $\mathrm{HBr}$ & + & $\mathrm{N}_{2} \mathrm{O}_{5}$ & $\longrightarrow$ & BrONO & + & $\mathrm{HNO}_{3}$ & -5.6 & I,II & & $0.005^{\S}$ & $0.005^{5}$ \\
\hline
\end{tabular}

The assumed radii used in this study for sulfate aerosol (A), PSC I (I) and PSC II (II) are $0.1 \mu \mathrm{m}, 0.1 \mu \mathrm{m}, 10 \mu \mathrm{m}$ respectively. $\mathcal{B}$, a bulk phase reaction. $\star$, a key reaction.

${ }^{\$}$ From Hanson and Ravishankara [1992].

${ }^{\dagger}$ From Abbatt [1994].

${ }^{\ddagger}$ From Hanson and Ravishankara [1995].

their diffusoreactive length. For example, as mentioned by Danilin and McConnell [1995], the diffusoreactive length of reaction (2) exceeds $1 \mu \mathrm{m}$ for $60 \mathrm{wt} \% \mathrm{H}_{2} \mathrm{SO}_{4}$ solution. The rates of the bulk phase reactions are calculated as a function of temperature by using a Henry's law coefficient and an aqueous phase bimolecular rate coefficient as described by Cox et al. [1994]. The bulk phase reactions are fastest at cold temperatures and for high water concentrations and are therefore most important in the region close to the tropopause or wherever the temperature falls below $210 \mathrm{~K}$.

In each case the bimolecular rate coefficient for the liquid phase reaction is taken to be $10^{5} \mathrm{M}^{-1} \mathrm{~s}^{-1}$. The effective Henry's law coefficient for $\mathrm{HCl}$ is calculated as a function of temperature and effective hydrogen concentration in the manner described by Cox et al. [1994]. The effective Henry's law coefficient for $\mathrm{HBr}$ is calculated after DeMore et al. [1994] (see also Brimblecombe and Clegg [1988]). The effective Henry's law coefficient for HOBr is taken to be $10^{6} \mathrm{M} / \mathrm{atm}$ in accordance with the results of Hanson and Ravishankara [1995] at $210 \mathrm{~K}$. In marked contrast to the hydrolysis of $\mathrm{ClONO}_{2}$ on sulfate aerosols, the hydrolysis of $\mathrm{BrONO}_{2}$ on sulfate aerosols (reaction (7) in Table 1 ) is not a strong function of temperature [Hanson and Ravishankara, 1995] (see Figure 3 later). Hanson and Ravishankara [1992] studied the heterogeneous reaction of $\mathrm{HBr}$ with $\mathrm{N}_{2} \mathrm{O}_{5}$ (reaction (8) in Table 1). Where $\gamma$ values were unavailable, the $\gamma$ values used for the bromine reactions were taken to be the same as those of their chlorine analogues.

The key heterogeneous bromine reactions are marked with a large star in Table 1. They involve the relatively abundant bromine species $\mathrm{HOBr}$ and $\mathrm{BrONO}_{2}$. The net effect of these reactions is to convert $\mathrm{BrO}_{y}$ from $\mathrm{BrONO}_{2}$ and $\mathrm{HBr}$ into $\mathrm{HOBr}$ and $\mathrm{BrCl}$. The $\mathrm{HOBr}$ can subsequently be photolyzed or heterogeneously converted into $\mathrm{BrCl}$.

\section{Heterogeneous Bromine Catalytic Cycles}

The hydrolysis of $\mathrm{BrONO}_{2}$ is the rate-limiting step of a catalytic cycle in which $\mathrm{H}_{2} \mathrm{O}$ is split and converted into $\mathrm{HO}_{2}$. Three ozone molecules are destroyed for each molecule of $\mathrm{BrONO}_{2}$ hydrolyzed.

$\begin{array}{llllll}\text { Cycle } \mathrm{A} & & & & & \\ \mathrm{BrONO}_{2} & +\mathrm{H}_{2} \mathrm{O} & & \mathrm{HOBr} & +\mathrm{HNO}_{3} \\ \mathrm{HNO}_{3} & +\mathrm{h} \nu & \longrightarrow & \mathrm{OH} & +\mathrm{NO}_{2} \\ \mathrm{OH} & + & \mathrm{O}_{3} & \longrightarrow & \mathrm{HO}_{2} & +\mathrm{O}_{2} \\ \mathrm{HOBr} & + & \mathrm{h} \nu & \longrightarrow & \mathrm{OH} & +\mathrm{Br} \\ \mathrm{OH} & + & \mathrm{O}_{3} & \longrightarrow & \mathrm{HO}_{2} & +\mathrm{O}_{2} \\ \mathrm{Br} & + & \mathrm{O}_{3} & \longrightarrow & \mathrm{BrO}_{2} & +\mathrm{O}_{2} \\ \mathrm{BrO} & + & \mathrm{NO}_{2} & \longrightarrow & \mathrm{BrONO}_{2} & \\ \mathrm{H}_{2} \mathrm{O} & + & 3 \mathrm{O}_{3} & \longrightarrow & 2 \mathrm{HO}_{2} & +3 \mathrm{O}_{2}\end{array}$

Cycle A is represented schematically in Figure 1. Cycle A has a long chain length for enhanced levels of sulfate aerosol reaching a peak of over $10^{3}$ between

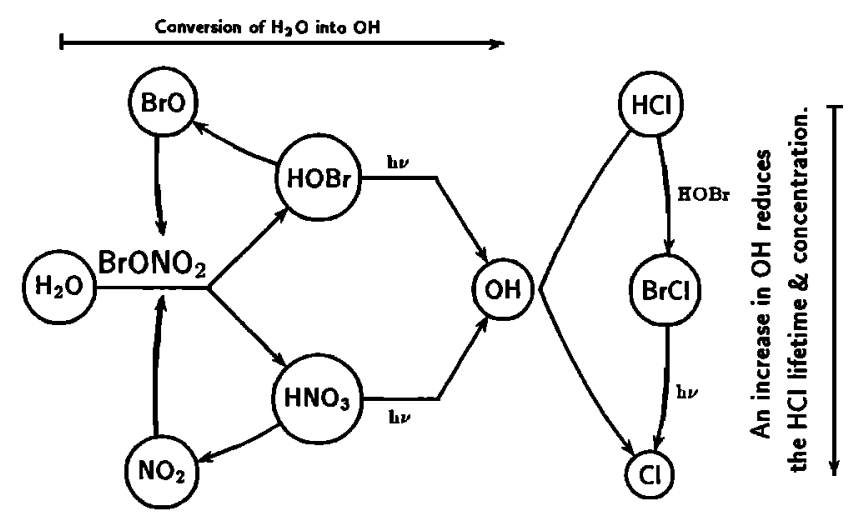

Figure 1. Reaction scheme showing the effects of $\mathrm{BrONO}_{2}$ hydrolysis on sulphate aerosols. 

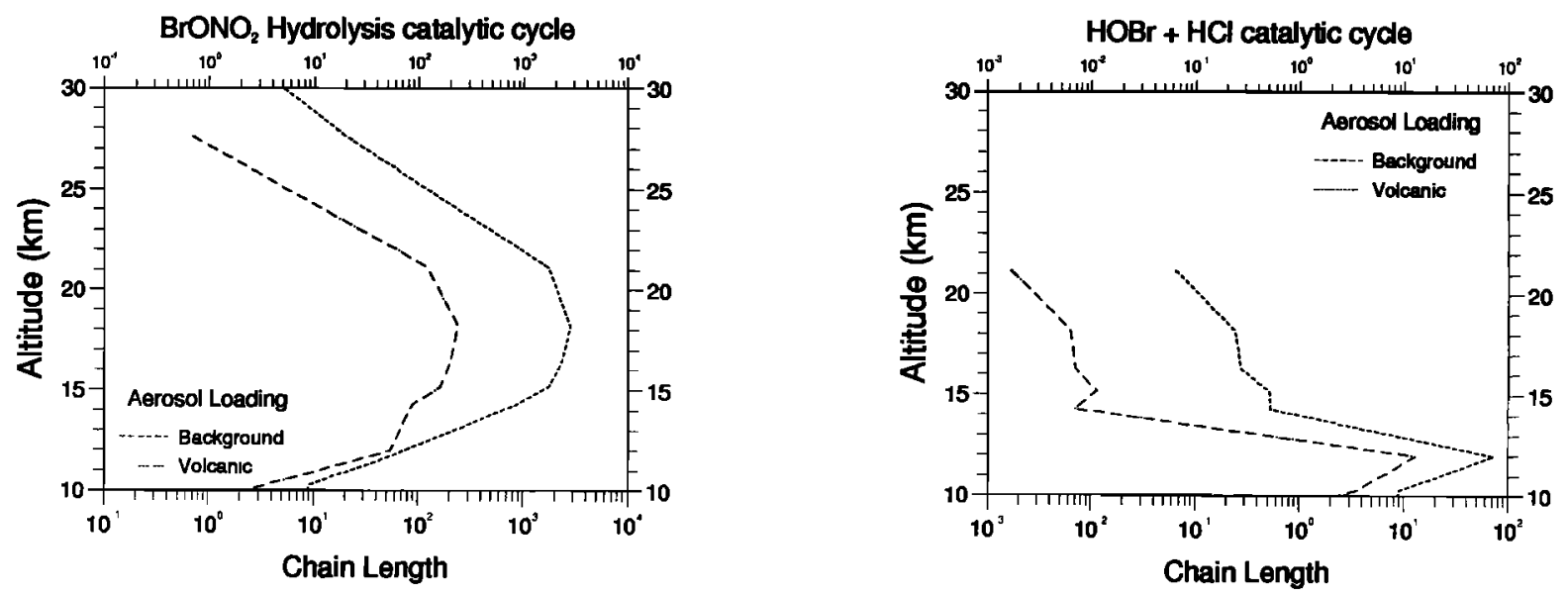

Figure 2. The chain lengths of the ozone destroying $\mathrm{BrONO}_{2}$ hydrolysis and the $\mathrm{HOBr}+\mathrm{HCl}$ catalytic cycles for background and volcanic loadings of sulphate aerosol.

about $15 \mathrm{~km}$ and $20 \mathrm{~km}$ (Figure 2). The chain length is a measure of how many times the cycle is completed before the chain center is removed. Because the chain length is a ratio of two rates, it is dimensionless. It is discussed in more detail in the companion paper [Lary, this issue] where it is defined as the rate of propagation (the rate of the rate-limiting step), $k_{\text {rls }}$ divided by the rate of production or destruction of the source gases, $k_{\text {dest }}$.

$$
\text { chain length, } \mathcal{N}=\frac{k_{\text {rls }}}{k_{\text {dest }}}
$$

The rate of the rate-limiting step reaches a peak of approximately 1600 molecules $\mathrm{cm}^{-3} \mathrm{~s}^{-1}$ close to $18 \mathrm{~km}$ for enhanced levels of sulfate aerosol, and approximately 150 molecules $\mathrm{cm}^{-3} \mathrm{~s}^{-1}$ for background levels of sulfate aerosol.

The sticking coefficient for hydrolysis of $\mathrm{BrONO}_{2}$ on sulfate aerosols is not temperature dependent. Cycle A can proceed whenever sunlight is present. It is therefore important for ozone loss at all latitudes and for all seasons in the lower stratosphere. For example, over a 40-day mid-latitude simulation of a vertical profile in a one-dimensional model at the equinox, including heterogeneous bromine reactions reduced the ozone column by $11.2 \%$ for volcanic aerosol loadings and by $5.4 \%$ for background aerosol loadings. The ozone loss due to heterogeneous bromine reactions took place in the troposphere and the lower stratosphere. Although this study did not include the effects of rain out in the troposphere, it is clear that heterogeneous bromine reactions are also important in the troposphere [Fan and Jacob, 1992; Finlayson-Pitts et al., 1990; McConnell et al., 1992; Toumi, 1994].

Cycle $\mathrm{A}$ enhances the $\mathrm{OH}$ concentration and thereby indirectly couples the atmospheric chemistry of chlorine and bromine, because the increase in the $\mathrm{OH}$ con- centration can reduce the $\mathrm{HCl}$ lifetime by up to a factor of 3 . The reduced $\mathrm{HCl}$ lifetime, and the accompanying increase in the $\mathrm{ClO}_{x}$ concentration, alters the $\mathrm{ClONO}_{2} / \mathrm{HCl}$ ratio, enhancing the effectiveness of the two gas phase $\mathrm{ClO} / \mathrm{BrO}$ catalytic cycles.

Both the production and destruction of $\mathrm{HNO}_{3}$ involve $\mathrm{OH}$. However, owing to the relative rates of these two reactions, the increase in the $\mathrm{OH}$ concentration increases the production of $\mathrm{HNO}_{3}$ more than it enhances the $\mathrm{HNO}_{3}$ destruction. As a result the ratio of the $\mathrm{HNO}_{3}$ production timescale to the $\mathrm{HNO}_{3}$ loss timescale increases from between 1.5 and 2 in the lower stratosphere to approximately 3 when heterogeneous bromine reactions on enhanced loadings of sulfate aerosols are included for noon at mid-latitudes at equinox. This increase in $\mathrm{OH}$ leads to an increase in the $\mathrm{HNO}_{3}$ concentration at the expense of the $\mathrm{NO}_{2}$ concentration.

At cold temperatures the $\mathrm{HOBr}$ formed by $\mathrm{BrONO}_{2}$ hydrolysis can react with $\mathrm{HCl}$ within sulfate aerosols to produce $\mathrm{BrCl}$ instead of being photolyzed. This cycle couples the atmospheric chemistry of chlorine and bromine, releasing active chlorine from $\mathrm{HCl}$. Each time the cycle is executed, $\mathrm{HCl}$ is converted into $\mathrm{ClO}$ and three ozone molecules are destroyed.

\section{Cycle B}

$\begin{array}{lllllll}\mathrm{BrONO}_{2} & +\mathrm{H}_{2} \mathrm{O} & \longrightarrow & \mathrm{HOBr} & +\mathrm{HNO}_{3} \\ \mathrm{HNO}_{3} & +\mathrm{h} \nu & \longrightarrow & \mathrm{OH} & +\mathrm{NO}_{2} \\ \mathrm{OH} & + & \mathrm{O}_{3} & \longrightarrow & \mathrm{HO} & & +\mathrm{O}_{2} \\ \mathrm{HOBr} & + & \mathrm{HCl} & \longrightarrow & \mathrm{BrCl} & +\mathrm{H}_{2} \mathrm{O} \\ \mathrm{BrCl} & + & \mathrm{h} \nu & \longrightarrow & \mathrm{Br} & +\mathrm{Cl} \\ \mathrm{Br} & + & \mathrm{O}_{3} & \longrightarrow & \mathrm{BrO} & +\mathrm{O}_{2} \\ \mathrm{Cl} & + & \mathrm{O}_{3} & \longrightarrow & \mathrm{ClO} & +\mathrm{O}_{2} \\ \mathrm{BrO} & + & \mathrm{NO}_{2} & \mathrm{M} & \mathrm{BrONO}_{2} & & \\ \mathrm{HCl} & + & 3 \mathrm{O}_{3} & \longrightarrow & \mathrm{HO}_{2}+\mathrm{ClO} & +3 \mathrm{O}_{2}\end{array}$

The rate of the bulk phase reactions (1) to (3) in Table 1 are a strong function of both the temperature 
and the water vapor concentration. Therefore cycle B is only effective in the cold temperatures found in the very low stratosphere. For enhanced aerosol loadings it has a chain length approaching 100 (Figure 2).

Figure 3 shows that the hydrolysis of $\mathrm{BrONO}_{2}$ on sulfate aerosols is effective over a wide range of temperatures. It can be seen that in absolute terms it has a relatively low rate, underlining the fact that its importance is due to its being part of a catalytic cycle. It is interesting that even though the sticking coefficient is not a function of temperature, the absolute rate of $\mathrm{BrONO}_{2}$ hydrolysis in units of molecules $\mathrm{cm}^{-3} \mathrm{~s}^{-1}$ is temperature dependent (Figure 3). This is because the $\mathrm{BrONO}_{2}$ concentration is very sensitive to the amount of $\mathrm{NO}_{2}$ present, which is in turn a function of the temperature and ozone concentration [Lary, 1991]; Lary et al., 1994]. A similar effect is observed in the rate of $\mathrm{N}_{2} \mathrm{O}_{5}$ hydrolysis (Figure 3 ). By comparing the rates of $\mathrm{BrONO}_{2}, \mathrm{~N}_{2} \mathrm{O}_{5}$ and $\mathrm{ClONO}_{2}$ hydrolysis shown in Figure 3 it illustrates that the reduction in $\mathrm{NO}_{x}$ and enhancement in $\mathrm{HNO}_{3}$ that occurs when $\mathrm{BrONO}_{2}$ hydrolysis is included is not due to the hydrolysis of $\mathrm{BrONO}_{2}$ alone, a relatively slow process, but is also due to the increase in $\mathrm{OH}$ released by the photolysis of the $\mathrm{HOBr}$ that is formed.

In agreement with the findings of Hanson and Ravishankara [1995] it was found that at temperatures below approximately $210 \mathrm{~K}$ the fastest stratospheric heterogeneous bromine reaction is the bulk phase reaction of $\mathrm{HOBr}$ with $\mathrm{HCl}$. At the tropopause and below, the high water concentrations enable the bulk phase reaction of $\mathrm{HOBr}$ with $\mathrm{HCl}$ to proceed very rapidly.

\section{Diurnal Cycles}

The hydrolysis of $\mathrm{BrONO}_{2}$ has a marked effect on the shape of the $\mathrm{BrONO}_{2}$ and $\mathrm{HOBr}$ diurnal cycles (Figure 4). During the day $\mathrm{BrONO}_{2}$ is rapidly produced by the three-body reaction of $\mathrm{BrO}$ with $\mathrm{NO}_{2}$, and the hydrolysis of $\mathrm{BrONO}_{2}$ is not fast enough to compete with the photolysis of $\mathrm{BrONO}_{2}$. Therefore at mid-latitudes $\mathrm{BrONO}_{2}$ hydrolysis has a relatively small effect on the daytime $\mathrm{BrONO}_{2}$ concentration. However, after sunset, $\mathrm{BrONO}_{2}$ production ceases and any $\mathrm{BrONO}_{2}$ present is converted into $\mathrm{HOBr}$ on the timescale of a few hours, so that at the end of the night little $\mathrm{BrONO}_{2}$ remains if enhanced aerosol loadings are present (Figure 4). $\mathrm{BrONO}_{2}$ would otherwise be a major $\mathrm{BrO}_{y}$ reservoir as the reaction of $\mathrm{BrO}$ with $\mathrm{NO}_{2}$ goes to completion. Consequently, the largest difference in the calculated $\mathrm{BrONO}_{2}$ concentration due to heterogeneous bromine reactions occurs just before dawn (Figure 4 ).

The increase in $\mathrm{HOBr}$ is due to the hydrolysis of $\mathrm{BrONO}_{2}$ during the night causes a sudden increase in the $\mathrm{OH}$ and $\mathrm{HO}_{2}$ concentrations at dawn as $\mathrm{HOBr}$ is rapidly photolyzed (Figure 4). This sudden dawn in- crease in $\mathrm{OH}$ and $\mathrm{HO}_{2}$ is in agreement with the recent SPADE observations of $\mathrm{OH}$ and $\mathrm{HO}_{2}$ reported by Salawitch et al. [1994]. The simulations shown in Figure 4 used the initial conditions given in table 1 of Salawitch et al. [1994] and assumed 14 pptv of $\mathrm{BrO}_{y}$. Salawitch et al. [1994] explained the sudden increase in $\mathrm{OH}$ and $\mathrm{HO}_{2}$ at sunrise by the heterogeneous conversion of $\mathrm{HO}_{2} \mathrm{NO}_{2}$ into HONO. However, Figure 4 shows that at least part of the sudden sunrise increase in $\mathrm{OH}$ and $\mathrm{HO}_{2}$ is due to $\mathrm{BrONO}_{2}$ hydrolysis enhancing the $\mathrm{HOBr}$ concentration. Hanson and Ravishankara [1995] mentioned that $\mathrm{BrONO}_{2}$ hydrolysis produces enough $\mathrm{HOBr}$ during the night to give a release of $\mathrm{OH}$ at dawn.

When using the $\mathrm{HOBr}$ cross sections of Orlando and Burkholder [1995] the inclusion of heterogeneous bromine reactions leads to a slightly lower $\mathrm{BrO}$ concentration for a short period immediately after dawn as $\mathrm{HOBr}$ is photolyzed slightly more slowly than $\mathrm{BrONO}_{2}$. The decrease in $\mathrm{BrO}$ in the short period just after dawn would not occur if $\mathrm{HOBr}$ photolysis was faster than $\mathrm{BrONO}_{2}$ photolysis. The bulk phase reaction of $\mathrm{HOBr}$ with $\mathrm{HCl}$ proceeds at night causing a slow, but steady, increase of $\mathrm{BrCl}$ during the night (Figure 4). At high latitudes in the cold stratosphere under volcanic conditions the reaction of $\mathrm{HOBr}$ with $\mathrm{HCl}$ proceeds at a much higher rate, leading to a coupling of bromine and chlorine chemistry (see also Danilin and Mc Connell [1995]).

\section{Partitioning of Reactive Species}

The inclusion of heterogeneous bromine reactions alters the $\mathrm{Br} / \mathrm{BrO}, \mathrm{Cl} / \mathrm{ClO}, \mathrm{NO} / \mathrm{NO}_{2}$ and $\mathrm{OH} / \mathrm{HO}_{2}$ ratios as well as altering the absolute concentrations of these species. There is an increase in the $\mathrm{BrO}_{x}, \mathrm{ClO}_{x}$ and $\mathrm{HO}_{x}$ concentrations and a decrease in the $\mathrm{NO}_{x}$ concentration. The $\mathrm{Br} / \mathrm{BrO}$ ratio is reduced when heterogeneous bromine reactions are included due to the decrease in the NO concentration, and hence the rate of the reaction of $\mathrm{BrO}$ with $\mathrm{NO}$. The $\mathrm{Cl} / \mathrm{ClO}$ ratio is reduced when heterogeneous bromine reactions are included due to the decrease in the NO concentration, and hence the rate of the reaction of $\mathrm{ClO}$ with NO. The $\mathrm{NO} / \mathrm{NO}_{2}$ ratio is reduced when heterogeneous bromine reactions are included due to the increase in the $\mathrm{ClO}$, $\mathrm{BrO}, \mathrm{HO}_{2}$ and $\mathrm{CH}_{3} \mathrm{O}_{2}$ concentrations, and hence, the rate of their reactions with $\mathrm{NO}$. The $\mathrm{OH} / \mathrm{HO}_{2}$ ratio is reduced when heterogeneous bromine reactions are included due to the decrease in the NO concentration and the increase in the $\mathrm{ClO}$ concentration. This decreases the rate of the reaction of $\mathrm{HO}_{2}$ with $\mathrm{NO}$ and increases the rate of the reaction of $\mathrm{ClO}$ with $\mathrm{OH}$.

During periods of enhanced aerosol loading the $\mathrm{HCl} /$ $\mathrm{ClO}_{y}$ ratio is reduced owing to the increase in $\mathrm{OH}$ by the catalytic hydrolysis of $\mathrm{BrONO}_{2}$ and a corresponding decrease in the $\mathrm{HCl}$ lifetime and concentration (Figure 5). The effect is most pronounced in the lower stratosphere. The decrease in the $\mathrm{HCl} / \mathrm{ClO}_{y}$ ratio is accompanied 

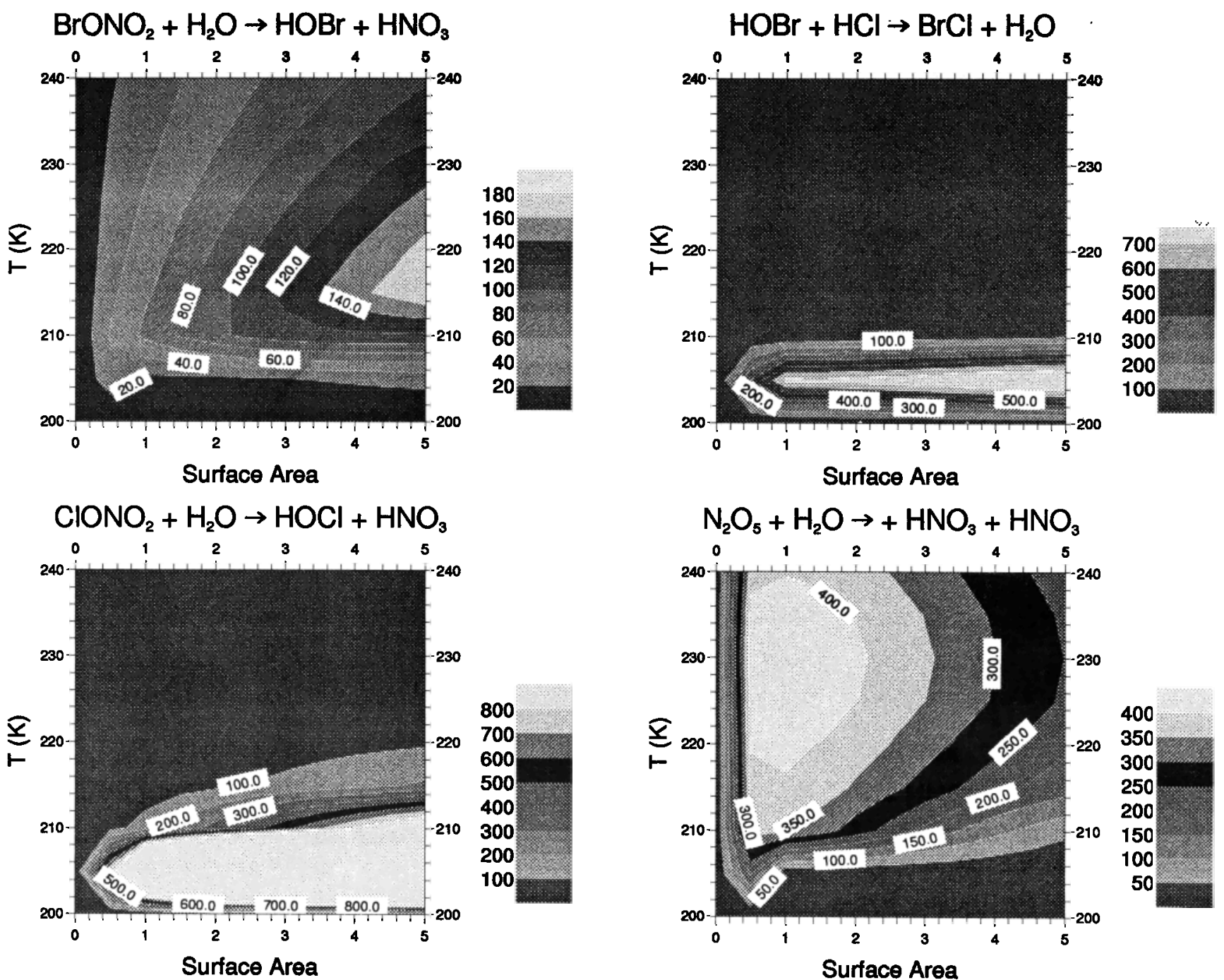

Figure 3. The absolute rate of heterogeneous reaction on sulphate aerosols at noon in units of molecules $\mathrm{cm}^{-3}$ $\mathrm{s}^{-1}$ as a function of temperature in $\mathrm{K}$ and aerosol surface area in units of $\mu \mathrm{m}^{2} / \mathrm{cm}^{3}$. The results shown are for the end of a 2-week simulation where an air parcel at $150 \mathrm{mb}, 45^{\circ} \mathrm{N}$ at equinox was kept at a given temperature with a given aerosol surface area present throughout the simulation. Please note that each plot has a different contour interval.

by an increase in the $\mathrm{ClO} / \mathrm{ClO}_{y}$ and $\mathrm{HOCl} / \mathrm{ClO}_{y}$ ratios (Figure 5). It would be useful to have simultaneous measurements of $\mathrm{HCl}, \mathrm{ClONO}_{2}$ and $\mathrm{HOCl}$ against which to critically test the photochemistry. Because the $\gamma$ value for the hydrolysis of $\mathrm{BrONO}_{2}$ is not temperature dependent, the reduction in the $\mathrm{HCl} / \mathrm{ClO}_{y}$ ratio by this mechanism is primarily dependent on the aerosol loading and is not critically dependent on temperature, latitude or solar zenith angle.

Since including heterogeneous bromine reactions affects the fraction of $\mathrm{BrO}_{y}$ in the form of $\mathrm{BrO}$ it also affects the $\mathrm{OClO}$ concentration. The increase in the $\mathrm{OClO}$ column at warmer mid-latitudes due to the inclusion of heterogeneous bromine reactions is much greater than the increase at colder high latitudes. As will be seen later, this is because the inclusion of heterogeneous bromine reactions has a smaller effect on the partition- ing of reactive bromine species at cold temperatures. For a 2-week simulation, at the equinox at $45^{\circ} \mathrm{N}$, including heterogeneous bromine reactions increased the midnight $\mathrm{OClO}$ column by a factor of just over 2 for background levels of sulfate aerosol and by a factor of almost 3 for enhanced levels of sulfate aerosol. In contrast, at high latitudes the increase in the $\mathrm{OClO}$ column is of the order of $10 \%$. This reinforces the finding of Sessler et al. [1995] that the OClO concentration is not a simple function of both $\mathrm{ClO}$ and $\mathrm{BrO}$.

\section{Gas Phase Catalytic Ozone Loss}

In addition to forming the catalytic cycles A and B already described, heterogeneous bromine reactions enhance the coupling between chlorine and bromine chemistry which occurs due to the two gas phase $\mathrm{ClO} / \mathrm{BrO}$ 


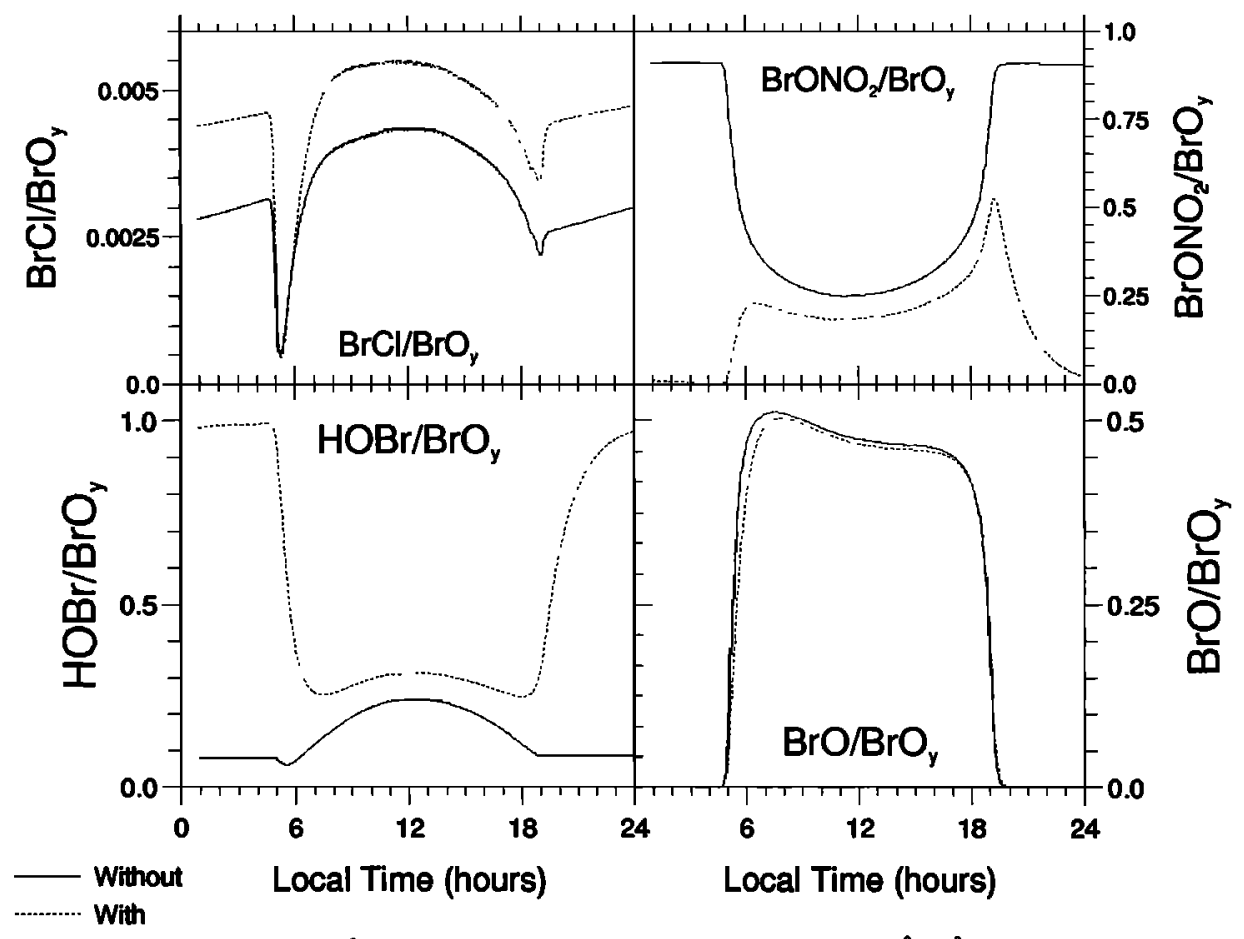

$37.9^{\circ} \mathrm{N}, 214.5 \mathrm{~K}, 66.9 \mathrm{mb}, 5 \mathrm{May}$, Aerosol area $=6 \mu \mathrm{m}^{2} \mathrm{~cm}^{.3}$.
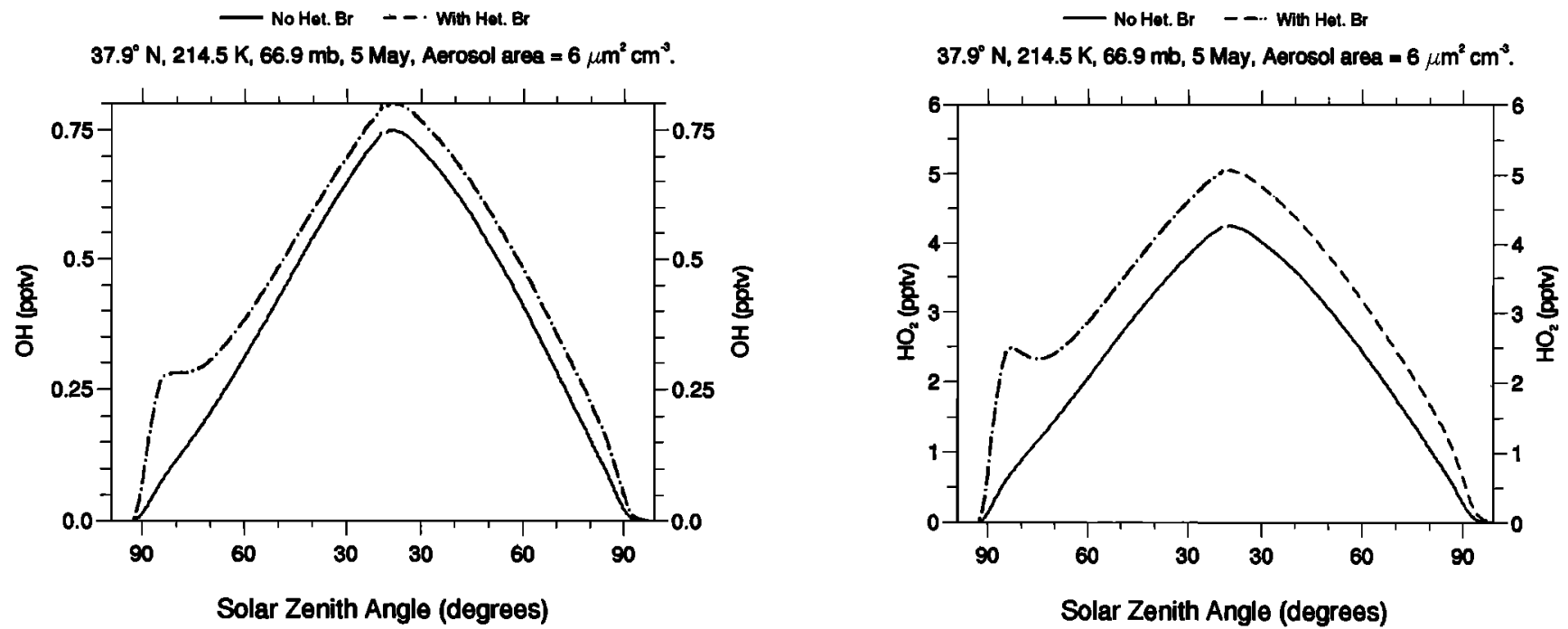

Figure 4. The effect of heterogeneous bromine reactions on sulfate aerosols on the shapes of diurnal cycles. The solid line is for a simulation which includes no heterogeneous bromine reactions, and the dashed line is for a simulation which does include heterogeneous bromine reactions. The initial conditions were taken from Table 1 of Salawitch et al. [1994].

catalytic ozone destruction cycles. The chain length of these two gas phase $\mathrm{ClO} / \mathrm{BrO}$ cycles is increased by nearly an order of magnitude from $10^{5}$ to $10^{6}$ when heterogeneous bromine reactions are included.

The chain length of the $\mathrm{BrO} / \mathrm{HO}_{2}$ catalytic cycle is approximately $10^{4}$ and is not significantly affected by heterogeneous bromine reactions. However, there is a decrease in the importance of the $\mathrm{BrO} / \mathrm{NO}_{2}$ ozone destruction catalytic cycle due to the hydrolysis of $\mathrm{BrONO}_{2}$ on sulfate aerosols. The $\mathrm{BrO} / \mathrm{NO}_{2}$ cycle was high- lighted by Burkholder et al. [1995] and is also examined by Lary [1995] together with a description of the gas phase catalytic bromine cycles. The $\mathrm{BrO} / \mathrm{NO}_{2}$ cycle only leads to ozone loss if the products of $\mathrm{BrONO}_{2}$ photolysis are $\mathrm{Br}$ and $\mathrm{NO}_{3}$.

To examine the effect of heterogeneous bromine reactions on lower stratosphere, mid-latitude, ozone loss, a set of idealized model simulations were performed. The numerical model is called AutoChem and is described in Lary et al. [1995] and Lary [this issue]. In 


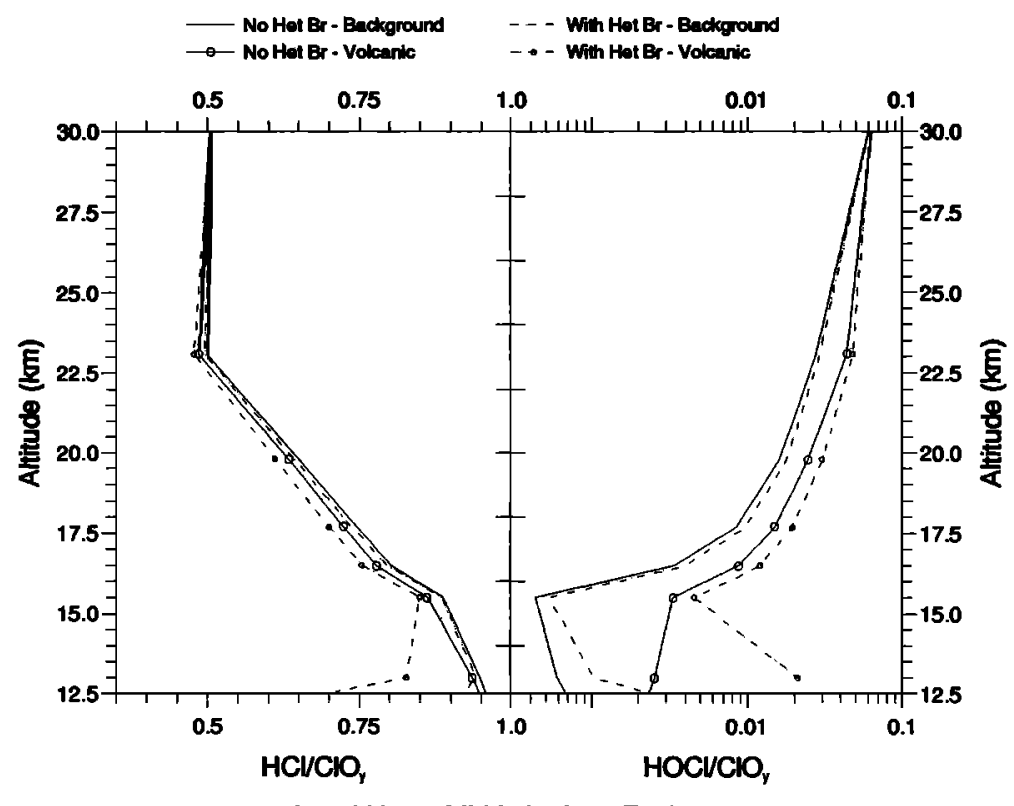

Local Noon, Mid-latitude at Equinox.

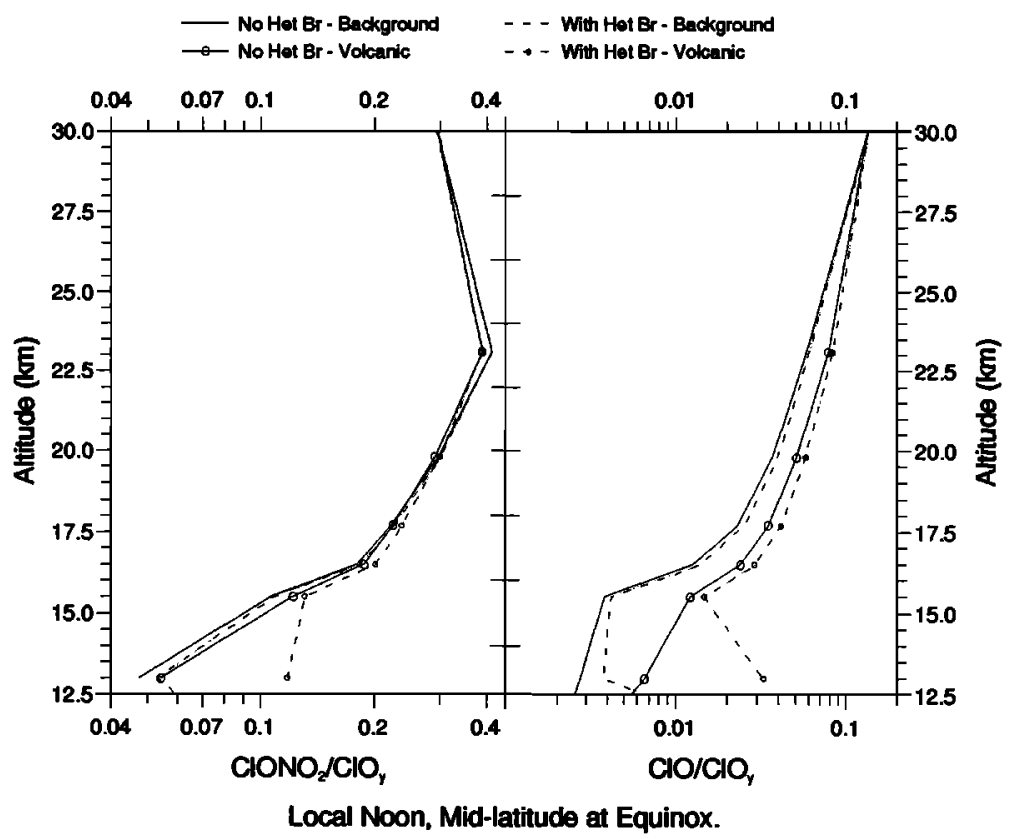

Figure 5. The effect of heterogeneous bromine reactions on sulfate aerosols on the calculated chlorine partitioning. The solid line is for no heterogeneous bromine reactions, and the dashed line is for with heterogeneous bromine reactions. The circles are for a volcanic aerosol loading.

these simulations the temperature of a stationary box was varied between $210 \mathrm{~K}$ and $198 \mathrm{~K}$ (Figure 6). This range of temperatures was chosen so that chlorine and bromine activation might occur on cold stratospheric aerosols without PSCs forming. For the first 10 days of the simulation the temperature was kept at $205 \mathrm{~K}$. For the next ten days of the simulation the temperature was kept at $200 \mathrm{~K}$. Then for 60 days the temperature was kept at $198 \mathrm{~K}$. The partitioning of bromine species during these simulations are shown in Figure 6.
When heterogeneous bromine reactions are not considered, the ozone concentration has decreased by 283 ppbv for background levels of aerosol and by $1430 \mathrm{ppbv}$ for volcanic levels of aerosol by the end of this idealized 100-day simulation (Figure 6). When heterogeneous bromine reactions are considered, the extra chlorine and bromine activation which occurs leads to an additional ozone depletion of approximately $60 \mathrm{ppbv}$ for background levels of aerosol (an increase of 21\%) and an additional $62 \mathrm{ppbv}$ for volcanic levels of aerosol 


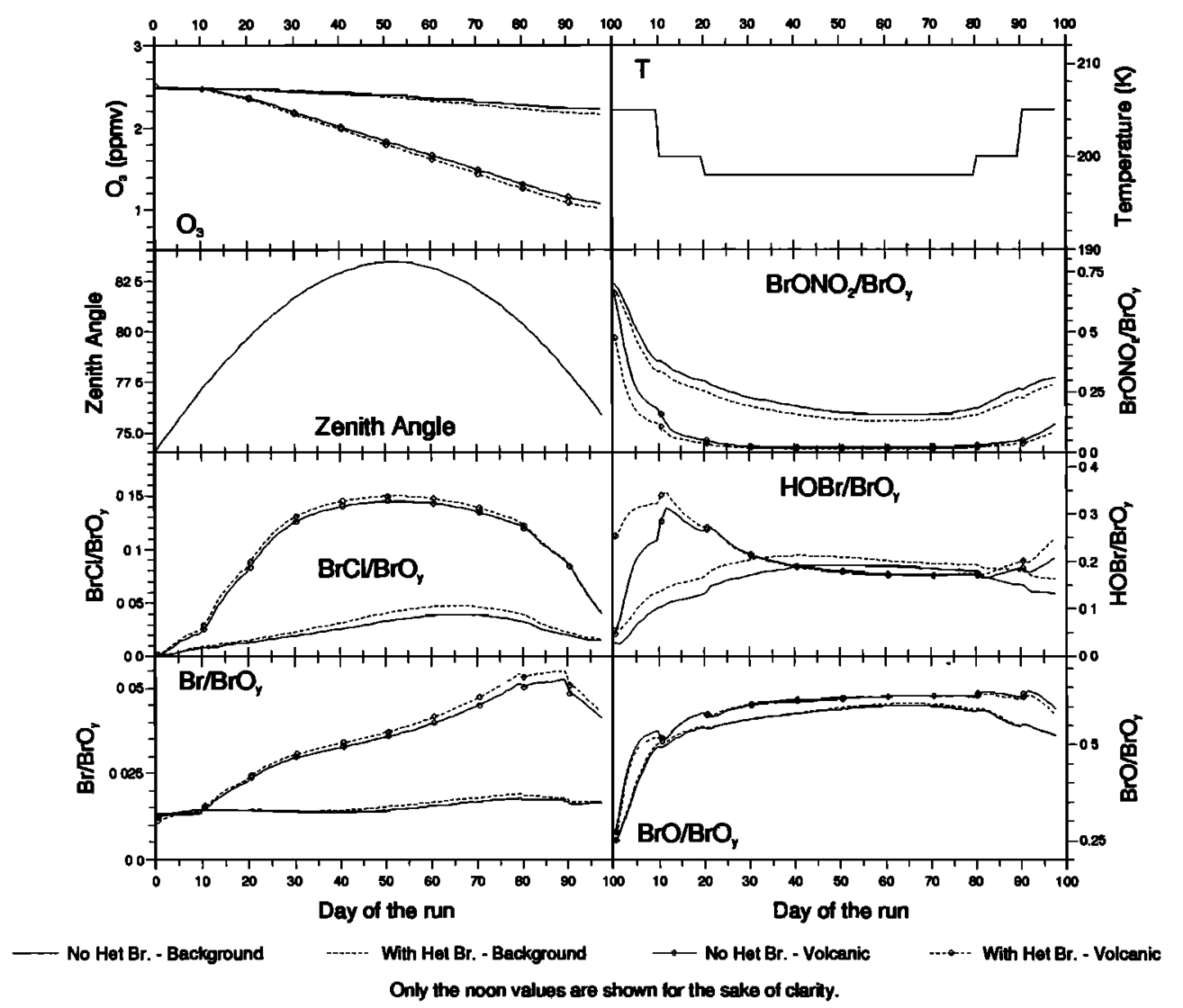

Figure 6. The effect of heterogeneous bromine reactions on the calculated noon partitioning of $\mathrm{BrO}_{y}$ for idealized box model simulations for an air parcel at $60^{\circ} \mathrm{N}$ at $55 \mathrm{mb}$ with background and volcanic aerosol loadings. The simulations start in autumn and go through to spring. The solid line in each case is for no heterogeneous bromine reactions, and the dashed line is for with heterogeneous bromine reactions. The circles are for a volcanic aerosol loading. Note, that only the noon partitioning is shown because the amplitude of the diurnal cycles is so large that it hampers a comparison of the two simulations over such a long (100 days) period.

(an increase of 4.3\%). Heterogeneous bromine reactions therefore contribute to mid-latitude, indeed all latitude, ozone loss in the lower stratosphere. Because the hydrolysis of $\mathrm{BrONO}_{2}$ is not temperature dependent, it enhances ozone loss throughout the year and at all latitudes.

Figure 7 shows that when heterogeneous bromine reactions are included there is an increase in $\mathrm{ClO}_{x}$ by day 20, as well as an increase in the $\mathrm{HO}_{x}$ and $\mathrm{BrO}_{x}$ concentrations. There is a coupling between chlorine and bromine chemistry which leads to chlorine as well as bromine activation. There has also been a drop in the $\mathrm{NO}_{x}$ and $\mathrm{HCl}$ concentrations. This is in agreement with the findings of Danilin and McConnell [1995].

The additional chlorine and bromine activation which occurs is due to heterogeneous bromine reactions on PSCs is not as significant as that due to heterogeneous bromine reactions on sulfate aerosols. This is not a reflection of the sticking coefficients but underlines the fact that the bromine species are much shorter-lived than their chlorine counterparts. Since $\mathrm{BrONO}_{2}$ and $\mathrm{HOBr}$ have such short lifetimes, the drop in the $\mathrm{NO}_{2}$ and $\mathrm{HO}_{2}$ concentrations which occurs immediately a
PSC is encountered also leads to a corresponding drop in the $\mathrm{BrONO}_{2}$ and $\mathrm{HOBr}$ concentrations. When a model simulation is performed with an air parcel in a PSC for extended periods of time, the calculated $\mathrm{HBr}$ and $\mathrm{BrONO}_{2}$ concentrations are virtually zero, and the $\mathrm{HOBr}$ concentration is very small. As a result, after an extended period in PSCs, the fastest PSC reaction is that of $\mathrm{HCl}$ with $\mathrm{HOBr}$. However, this has a rate which is between 1 and 2 orders of magnitude less than the analogous bulk phase reaction in cold sulfate aerosols shown in Figure 3.

Consequently, whether or not heterogeneous bromine reactions are included, when PSCs are present there is relatively little bromine present as $\mathrm{BrONO}_{2}$ and $\mathrm{HOBr}$ to react heterogeneously, and so a large fraction of the reactive bromine present is converted into $\mathrm{BrCl}$. However, a heterogeneous reaction involving $\mathrm{BrCl}$ on PSCs could be significant. At present the authors know of no heterogeneous $\mathrm{BrCl}$ reactions. In the presence of sunlight $\mathrm{BrCl}$ is of course rapidly photolyzed to release $\mathrm{Br}$ and $\mathrm{Cl}$, so any heterogeneous $\mathrm{BrCl}$ reaction would be most important at night.

The most noticeable effect of including heterogeneous 


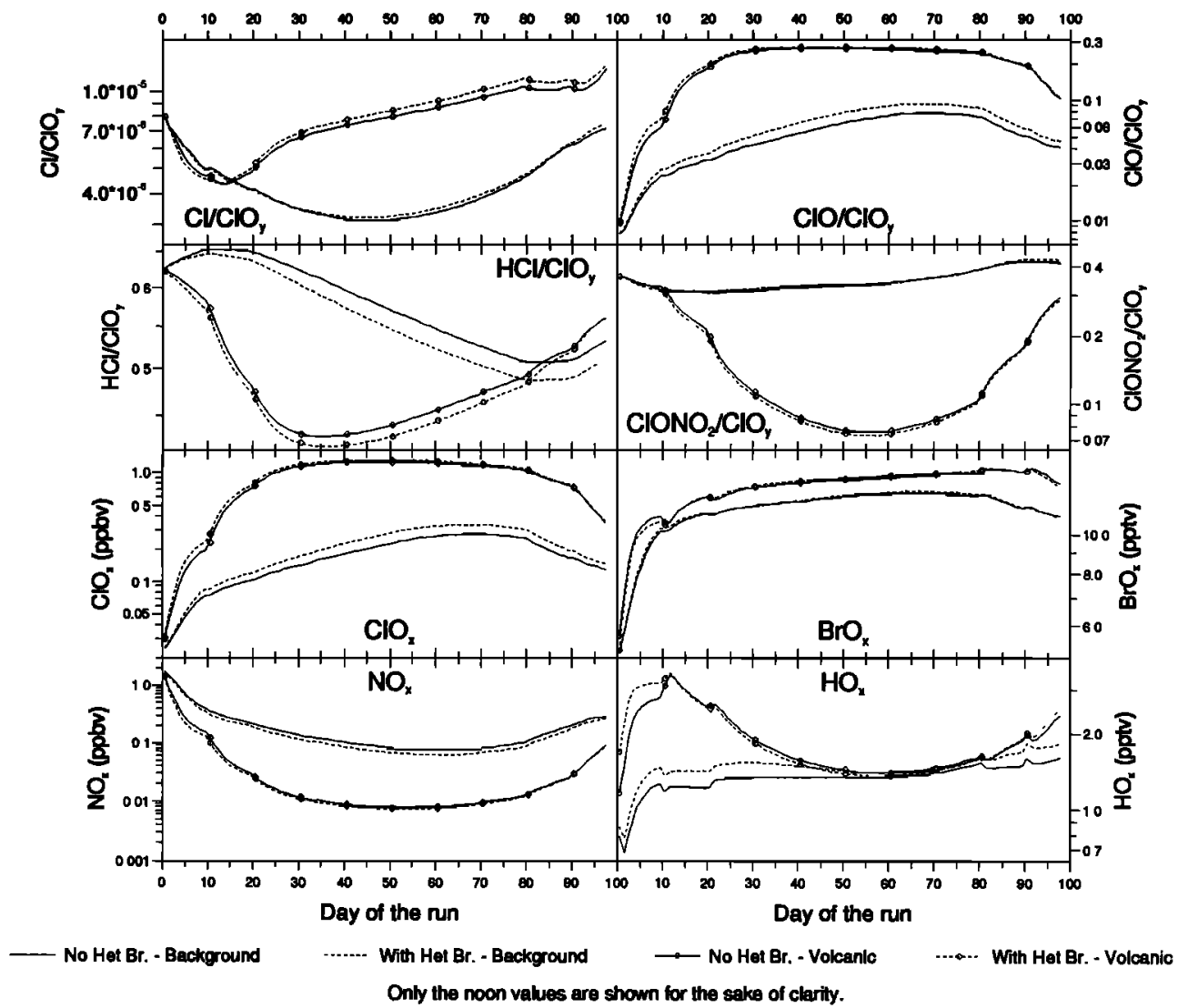

Figure 7. The effect of heterogeneous bromine reactions on the calculated noon partitioning of $\mathrm{ClO}_{y}$ and the $\mathrm{NO}_{x}, \mathrm{HO}_{x}, \mathrm{ClO}_{x}$ and $\mathrm{BrO}_{x}$ volume mixing ratios for idealized box model simulations for an air parcel at $60^{\circ} \mathrm{N}$ at $55 \mathrm{mb}$ with background and volcanic aerosol loadings. The simulations start in autumn and go through to spring. The solid line in each case is for no heterogeneous bromine reactions, and the dashed line is for with heterogeneous bromine reactions. The circles are for a volcanic aerosol loading. Note, that only the noon partitioning is shown because the amplitude of the diurnal cycles is so large that it hampers a comparison of the two simulations over such a long (100 day) period.

bromine reactions in the model is the dramatic drop in the $\mathrm{HBr}$ concentration. Although $\mathrm{HBr}$ usually only represents a small fraction of $\mathrm{BrO}_{y}$, after prolonged PSC processing the enhanced levels of $\mathrm{Cl}$ lead to an enhancement in methane oxidation and consequently the concentration of $\mathrm{HO}_{2}$. The enhanced $\mathrm{HO}_{2}$ concentration can lead to an enhanced production of $\mathrm{HBr}$, such that if heterogeneous bromine reactions are not included, more than $20 \%$ of $\mathrm{BrO}_{y}$ can be in the form of $\mathrm{HBr}$. When there is rapid removal of $\mathrm{HBr}$ by heterogeneous bromine reactions, $\mathrm{HBr}$ does not represent a significant fraction of $\mathrm{BrO}_{y}$.

The relative importance of the various heterogeneous bromine reactions on PSCs varies with the conditions, but the most important heterogeneous reactions tend to be the mixed halogen reactions, particularly reactions (2), (3) and (5) in Table 1, namely, the heterogeneous reactions of of $\mathrm{HCl}$ with $\mathrm{HOBr}$ and $\mathrm{BrONO}_{2}$ and $\mathrm{HBr}$ with $\mathrm{HOCl}$. This is just a reflection of the fact that the most abundant bromine species which undergo heterogeneous reactions are generally $\mathrm{BrONO}_{2}$ and $\mathrm{HOBr}$, and that $\mathrm{HCl}$ is an important chlorine reser- voir. Consequently, simply from concentration considerations, the heterogeneous reactions of $\mathrm{BrONO}_{2}$ and $\mathrm{HOBr}$ with $\mathrm{HCl}$ are important. In contrast, the reactions of $\mathrm{HBr}$ with $\mathrm{HOCl}$ and $\mathrm{ClONO}_{2}$ are key reactions in the model because they keep the $\mathrm{HBr}$ concentration small. It would be valuable to have more laboratory studies of these reactions. It is important to note that the model description of bromine partitioning would change dramatically if there is a significant source of $\mathrm{HBr}$ which exists in reality which has not been included in the model. The model currently predicts that where aerosols are present the $\mathrm{HBr}$ concentration should be small. It would therefore be valuable to have observations of $\mathrm{HBr}$ with which the model could be compared. If these observations show that $\mathrm{HBr}$ is in fact present in appreciable quantities in regions where sulfate aerosols are present, it means that there is an important additional source of $\mathrm{HBr}$.

In the next section the wide range of situations encountered on the $475 \mathrm{~K}$ isentropic surface during early 1993 are considered. Associated with the wide range of temperatures present on the $475 \mathrm{~K}$ isentropic surface 
$T$ on the $475.0 \mathrm{~K}$ isentrope

ECMWF analysis - 22 February 1993 - Time:12 00 GMT

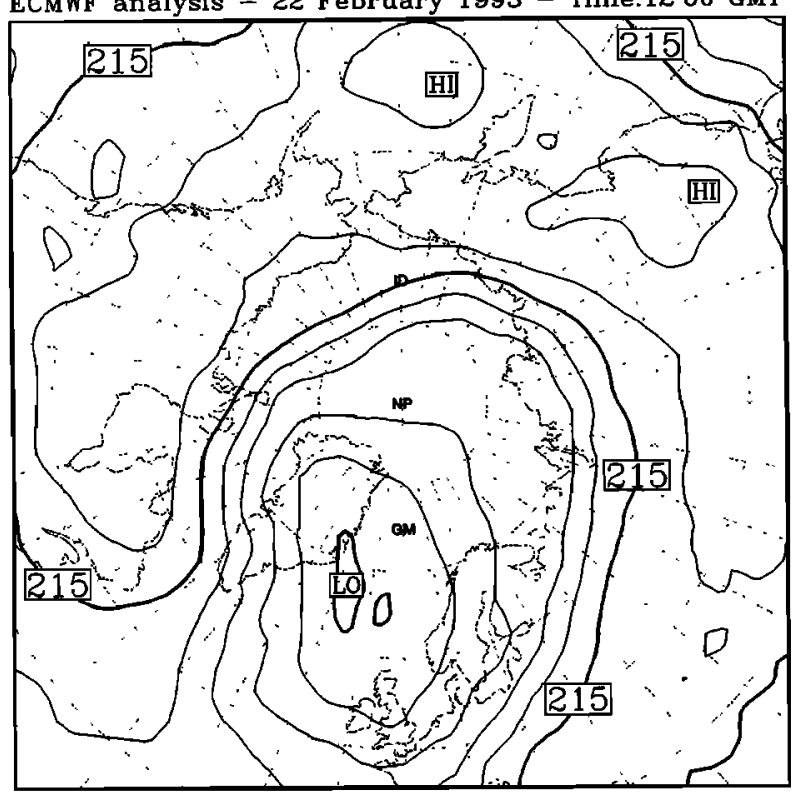

Contour from 190 to 225 by 5
PV on the $475.0 \mathrm{~K}$ isentrope.

ECMWF analysis - 22 February 1993 - Time: 1200 GMT

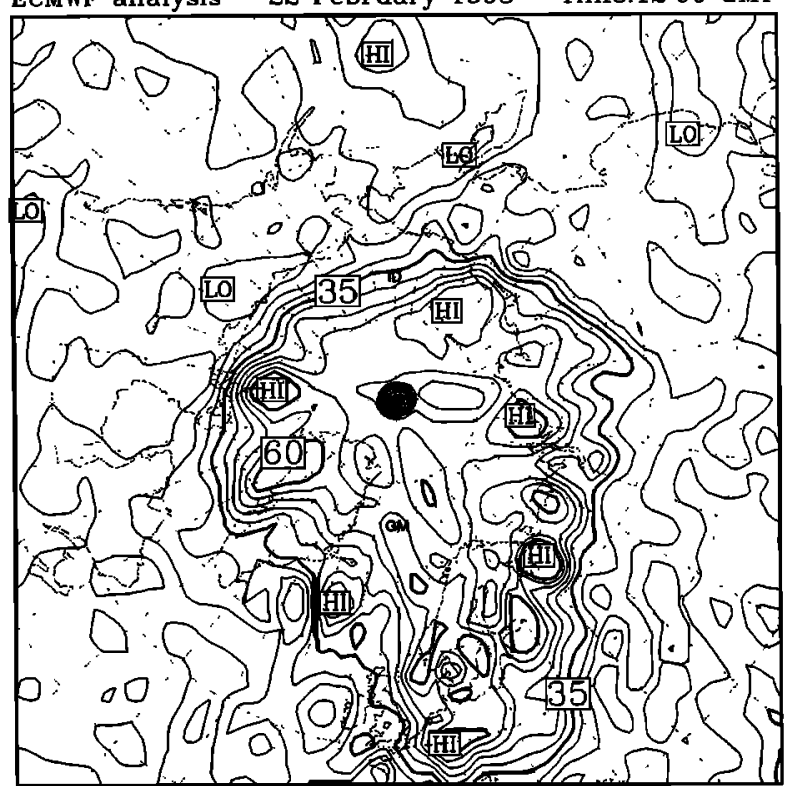

Contour from 10 to 60 by 5

Figure 8. The ECMWF temperature and PV analysis for the $475 \mathrm{~K}$ isentropic surface at $12 \mathrm{GMT}$ for the February 22, 1992.

there are quite large variations in pressure, with much lower pressures in the cold regions.

\section{Isentropic Model Simulations of the Winter of 1993}

Relative to the interannual variability observed in the northern hemisphere lower stratospheric temperatures, the winter of 1992-1993 can be classed as long and cold. PSCs were present in the lower stratosphere from early December 1992 until late February 1993 [Chipperfield, 1994]. During January the vortex was centered on the pole, but during February, distortions to the vortex ensured that air parcels traveling around its edge made excursions to sunlit latitudes. For example, Figure 8 shows the potential vorticity (PV) and temperature fields at $475 \mathrm{~K}$ on February 22, 1993. On this day the polar vortex is distorted and descends over Europe. The lowest temperatures of $190 \mathrm{~K}$ occur to the east of Greenland, permitting PSCs to form in this region.

This section considers the effect of heterogeneous bromine reactions by including them in a two-dimensional single level isentropic model, SLIMCAT, described by Chipperfield et al. [1993, 1994, 1995], Chipperfield [1994] and Lary et al. [1995]. This model was run at an altitude of $475 \mathrm{~K}$ using winds analysed by the European Centre for Medium-Range Weather Forecasts (ECMWF) from 1 January, 1993, until 1 March, 1993. The two-dimensional model also has a detailed chemical scheme with the heterogeneous bromine reactions included as described above. Six model simulations were performed (Table 2). Simulations SC1 (without heterogeneous bromine reactions) and SC2 (with heterogeneous bromine reactions) assumed a $0 \%$ yield for $\mathrm{HBr}$ from the reaction of $\mathrm{HO}_{2}$ with $\mathrm{BrO}$ (reaction (1b) discussed by Lary [this issue] and referred to as reaction (1b) hereafter). Simulations SC3 and SC4 were similar to experiments $\mathrm{SC} 1$ and $\mathrm{SC} 2$ respectively, but reaction (1b) was assumed to have a $1 \%$ channel. Finally, experiments SC5 and SC6 were similar to SC1 and SC2, respectively, but with an enhanced aerosol loading of $15 \mu \mathrm{m}^{2} / \mathrm{cm}^{3}$.

By comparing experiments $\mathrm{SC} 1$ and $\mathrm{SC} 2$ it was seen that inclusion of the heterogeneous bromine reactions significantly modified the partitioning of $\mathrm{BrO}_{y}$ species (not shown). As already observed, including heterogeneous bromine reactions gives additional ozone loss at all latitudes. The peak additional accumulated ozone loss predicted over the 2-month integrations was approximately $21 \mathrm{ppbv}$ at northern midlatitudes $(1.0 \%$, Figure 9(a)). The additional loss decreased at northern high latitudes and was a minimum at the center of the north polar vortex. Therefore the most important effect of including heterogeneous bromine reactions in experiment SC2 is due to the reactions on sulfate aerosols with a minor effect due to reactions on PSCs.

Experiments SC5 and SC6 were initialized with an aerosol loading of $15 \mu \mathrm{m}^{2} / \mathrm{cm}^{3}$, corresponding to conditions after a moderate volcanic eruption. Figure 10 shows the distribution of bromine species from the two-diemsional model on February 22, 1993, from run SC6 (with heterogeneous bromine reactions). The total 
Table 2. Summary of SlimCat Model Experiments

\begin{tabular}{|c|c|c|c|}
\hline Run & $\begin{array}{c}\text { Heterogeneous } \\
\text { Bromine Reactions }\end{array}$ & $\begin{array}{c}\text { Aerosol Area } \\
\mu \mathrm{m}^{2} / \mathrm{cm}^{3}\end{array}$ & $\begin{array}{l}\text { Quantum Yield } \\
\text { of reaction (1B) }\end{array}$ \\
\hline $\mathrm{SC} 1$ & no & 1 & 0 \\
\hline $\mathrm{SC} 2$ & yes & 1 & 0 \\
\hline SC3 & no & 1 & 0.01 \\
\hline $\mathrm{SC} 4$ & yes & 1 & 0.01 \\
\hline SC5 & no & 15 & 0 \\
\hline SC6 & yes & 15 & 0 \\
\hline
\end{tabular}

abundance of $\mathrm{BrO}_{y}$ at the center of the vortex is around 20 pptv. In the sunlit vortex the main bromine species is BrO with a peak mixing ratio of 9 pptv. Figure $10(\mathrm{~b})$ shows that the main nighttime reservoir of $\mathrm{BrO}_{y}$ in the $\mathrm{PSC}$-processed vortex is $\mathrm{BrCl}$ with peak mixing ratio of around 15 pptv. Owing to the rapid hydrolysis of $\mathrm{BrONO}_{2}$ on sulfate aerosols, $\mathrm{HOBr}$ is the main nighttime reservoir outside the PSC-processed region, but the mixing ratio inside the vortex is lower. The maximum mixing ratio of $\mathrm{HOBr}$ in the sunlit polar vortex is around 6 pptv. Figure 10(d) shows the distribution of $\mathrm{HBr}$ from run SC6 with heterogeneous bromine reactions included. The highest values of only $0.006 \mathrm{pptv}$ occur within the PSC region. Without heterogeneous bromine reactions (run SC5, not shown) the $\mathrm{HBr}$ mixing ratio is much higher but still only $0.3-0.5$ pptv at midlatitudes, decreasing inside the polar vortex to around $0.2 \mathrm{pptv}$ (not shown). However, these mixing ratios are still low, and $\mathrm{HBr}$ is only a minor component of the total inorganic bromine at this altitude. The twodimensional model has a simpler $\mathrm{CH}_{4}$ oxidation scheme than the box model and so does not produce as much $\mathrm{HBr}$ as the box model in PSC regions (see above). The low abundance of $\mathrm{HBr}$ and $\mathrm{BrONO}_{2}$ predicted in run SC5 (and also run SC1) in the Arctic polar vortex limits the effect of the heterogeneous bromine reactions which occur on PSCs.

Comparison of run SC5 and run SC6 shows the effect of including heterogeneous bromine reactions un- der volcanic aerosol loading. In early March the difference in ozone between run SC6 and SC5 is around $25 \mathrm{ppbv}$ in the northern polar vortex, around $40 \mathrm{ppbv}$ at northern mid-latitudes, and interestingly, a maximum of $150 \mathrm{ppbv}$ during summer at the high southern latitudes (Figure 9(b)). This is due to the enhanced $\mathrm{HO}_{x}$ concentration (Figure 11(e)) which has been produced by the catalytic hydrolysis of $\mathrm{BrONO}_{2}$ (cycle A). This finding emphasizes that heterogeneous bromine reactions can catalytically enhance ozone loss at all latitudes in all seasons.

Figure 11 shows the difference in some bromine species, $\mathrm{ClO}_{x}$ and $\mathrm{HO}_{2}$ between $\mathrm{SC} 5$ and SC6. As was found in the earlier idealized simulations, in regions of PSC processing there is an almost complete removal of $\mathrm{HBr}$ (not shown). $\mathrm{HBr}$ has also been completely removed at mid-latitudes. The only region where $\mathrm{HBr}$ remains is coincident with the PSC region between Iceland and Scandinavia (Figure 10). The $\mathrm{HBr}$ has been reduced by up to $0.5 \mathrm{pptv}$. The bromine released from the $\mathrm{HBr}$ has been photochemically repartitioned among the major bromine species, as would be expected from their short lifetimes. On February 22 the largest increase in $\mathrm{BrO}$ between runs SC6 and SC5 of 2.5 pptv also occurs at high southern latitudes, while in the northern hemisphere the increase is similar to that seen between the background aerosol runs SC2 and SC1 (not shown). The heterogeneous removal of $\mathrm{HBr}$ has led to a small increase in $\mathrm{BrO}$ of around $0.1 \mathrm{pptv}$ inside

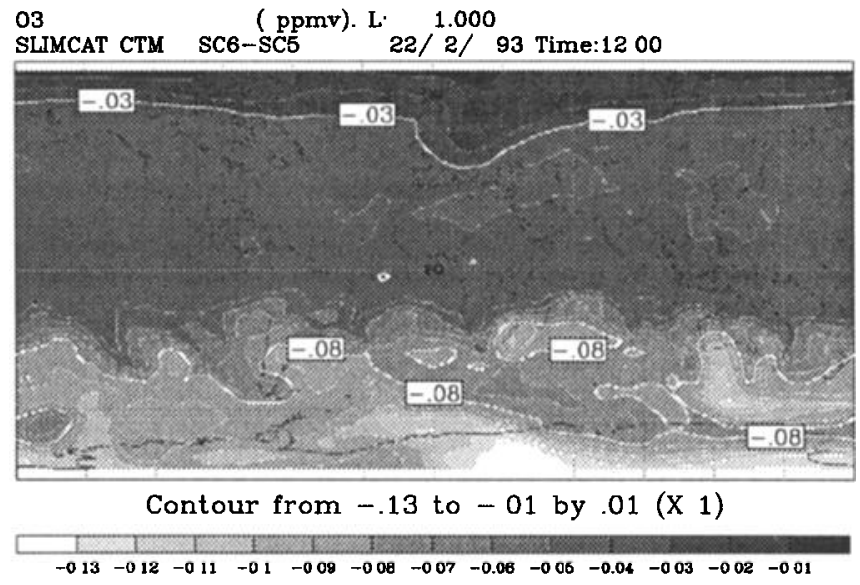

Figure 9. Difference in the ozone mixing ratio (ppmv) near the end of the 2-month simulations between (a) SC2 and SC1 and (b) SC6 and SC5. Different contour intervals are used in Figures 9(a) and 9(b). 

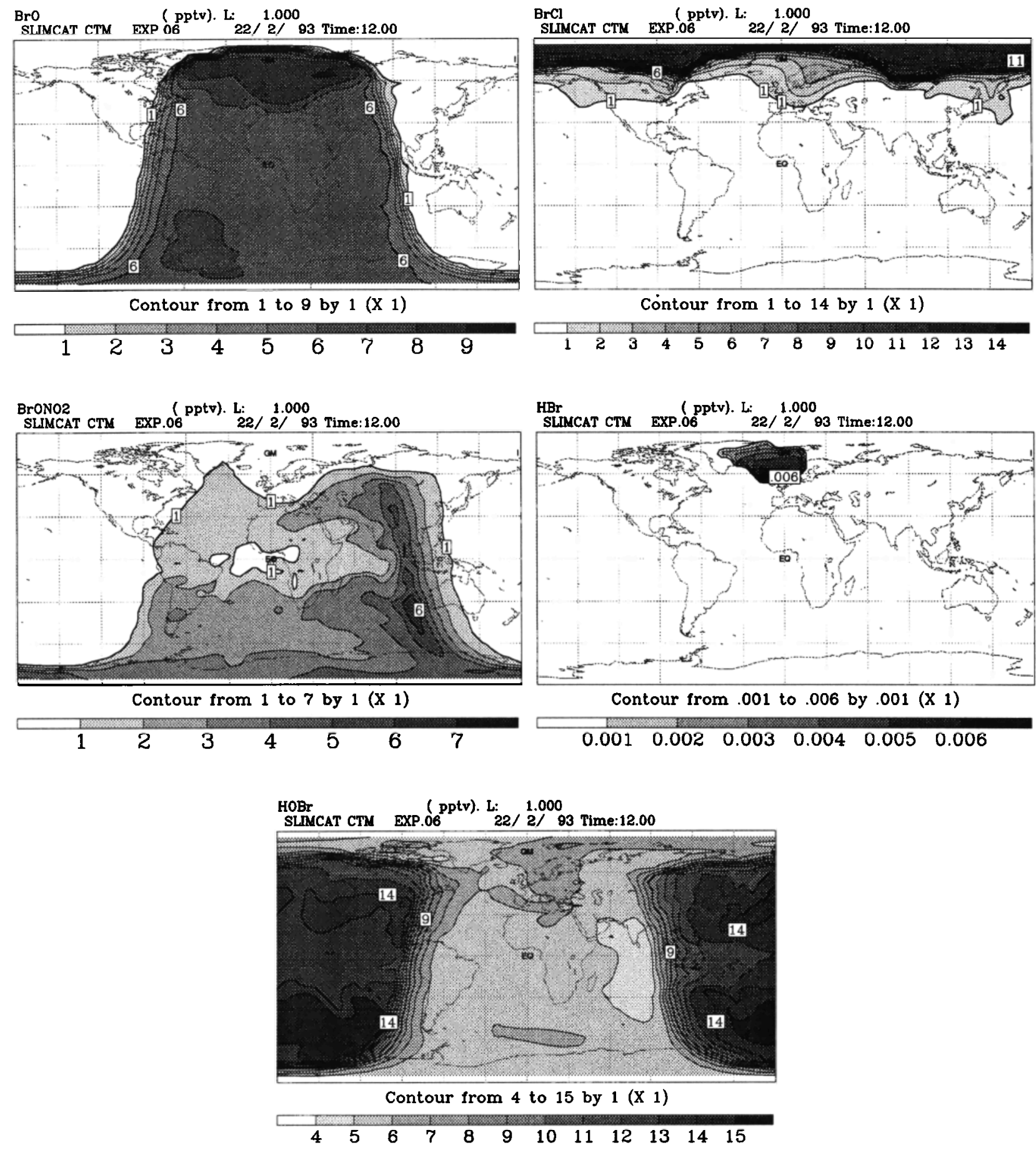

Figure 10. Mixing ratio (pptv) of (a) $\mathrm{BrO}$, (b) $\mathrm{BrCl}$, (c) $\mathrm{BrONO}_{2}$, (d) $\mathrm{HBr}$ and (e) $\mathrm{HOBr}$ at $475 \mathrm{~K}$ on February 22, 1993, from the two-dimensional model run with heterogeneous bromine reactions and volcanic aerosol loading (SC6).

the polar vortex. As was observed in the earlier idealized experiments, including heterogeneous bromine reactions slightly reduces the $\mathrm{BrO}$ concentration immediately after dawn (Figure $11(\mathrm{a})$ ) as $\mathrm{HOBr}$ is photolyzed at a slightly slower rate than $\mathrm{BrONO}_{2}$. The heterogeneous hydrolysis of $\mathrm{BrONO}_{2}$ on sulfate aerosols efficiently converts $\mathrm{BrONO}_{2}$ to $\mathrm{HOBr}$. With the higher aerosol loading the nighttime conversion of $\mathrm{BrONO}_{2}$ to $\mathrm{HOBr}$ is more rapid and effectively complete at an early stage of the night. The conversion of $\mathrm{BrONO}_{2}$ is also rapid during the day and accounts for the reduction of 7 pptv of $\mathrm{BrONO}_{2}$ at high southern latitudes. As well as the increase in $\mathrm{BrO}$ there is an increase of $4 \mathrm{pptv}$ in $\mathrm{HOBr}$. Under high aerosol loading the rates of the heterogeneous bromine reactions compete with the rapid daytime gas phase reactions which normally control the $\mathrm{BrO}_{\mathrm{y}}$ partitioning. Figure 11 shows that this conversion is most effective at night. Just before sunrise 

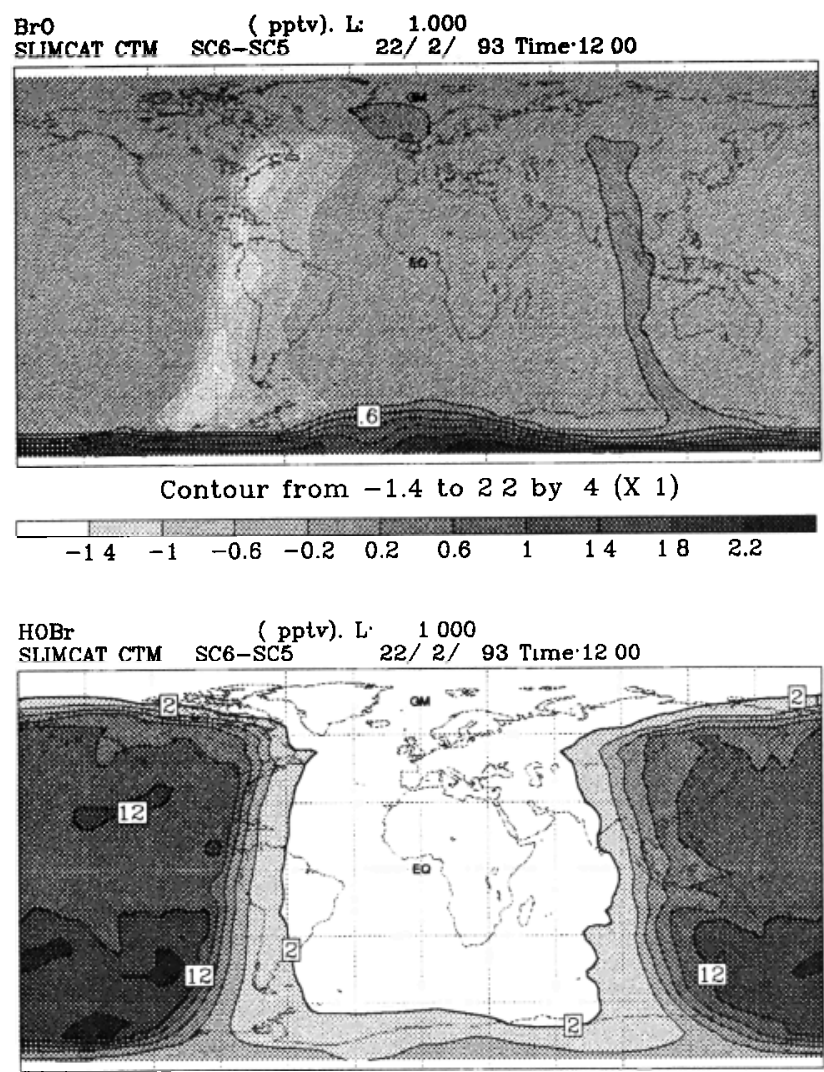

Contour from 2 to 14 by 2 (X 1 )

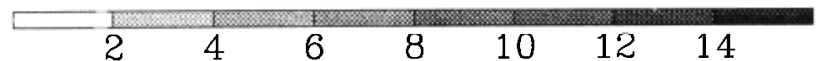

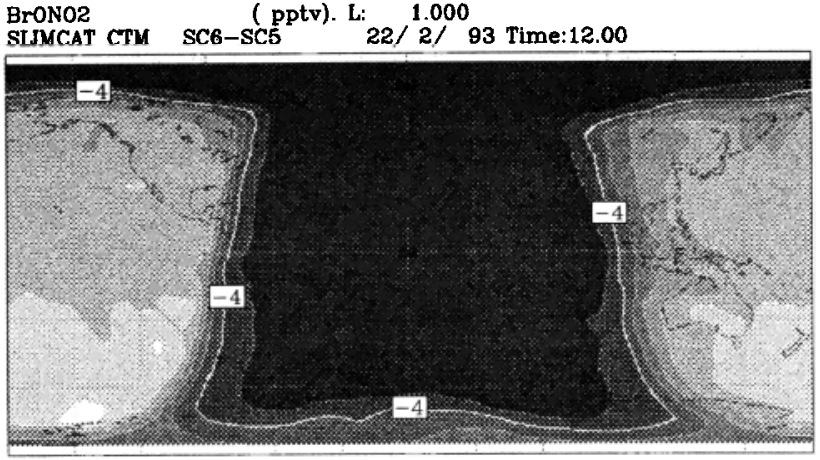

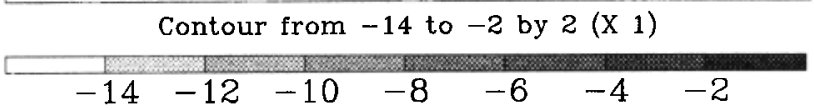

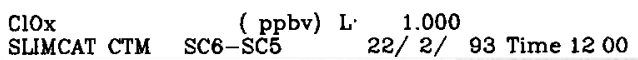

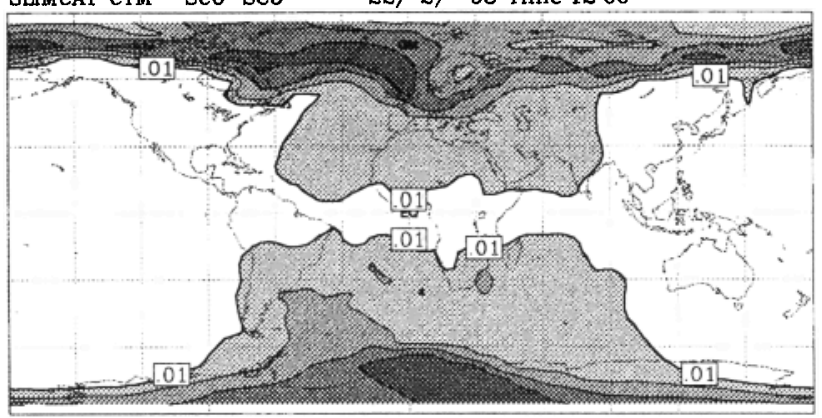

Contour from 01 to 05 by 01 (X 1)

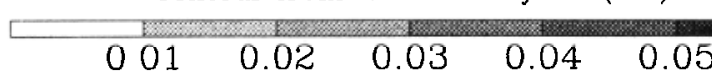

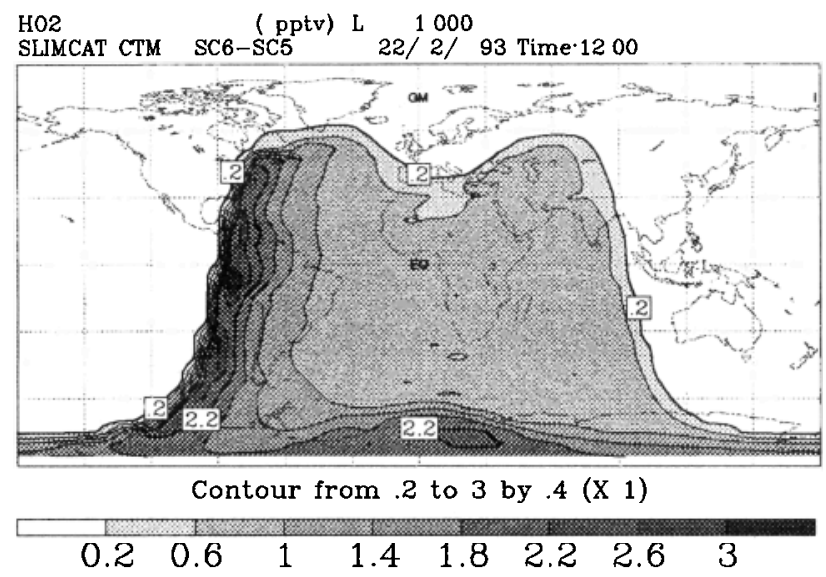

Figure 11. Difference in mixing ratio (pptv) between the two-dimensional model run with heterogeneous bromine reactions minus run without (SC6-SC5) for (a) $\mathrm{BrO}$, (b) $\mathrm{BrONO}_{2}$, (c) $\mathrm{HOBr}$ (d) $\mathrm{ClO}_{x}$ and (e) $\mathrm{HO}_{2}$ at $475 \mathrm{~K}$ on 22 February 1993 . The simulations used a volcanic aerosol loading.

there is 12 pptv more of $\mathrm{HOBr}$ in run SC6. During the daytime, photochemical reactions rapidly partition the $\mathrm{BrO}_{\mathrm{y}}$ species and produce $\mathrm{BrONO}_{2}$, and so the heterogeneous reactions have a much smaller effect than the gas phase reactions which normally control the $\mathrm{BrO}_{y}$ partitioning. There is up to 50 pptv more $\mathrm{ClO}_{x}$ in run SC6 at high southern latitudes and in PSC regions in the north polar vortex. Finally, $\mathrm{HO}_{2}$ has increased by up to $2.2 \mathrm{pptv}$ just after sunrise and during polar day in the southern hemisphere.

The catalytic increase in $\mathrm{OH}$ due to the hydrolysis of $\mathrm{BrONO}_{2}$ leads to a reduction in the $\mathrm{HCl}$ lifetime and the $\mathrm{HCl} / \mathrm{ClO}_{y}$ ratio. This can be seen in Figure 12 which shows the $\mathrm{HCl} / \mathrm{ClO}_{y}$ ratio for simulations SC2 and SC6. The substantial reduction in the mid-latitude $\mathrm{HCl} / \mathrm{ClO}_{y}$ ratio is particularly noticeable in the simu- 

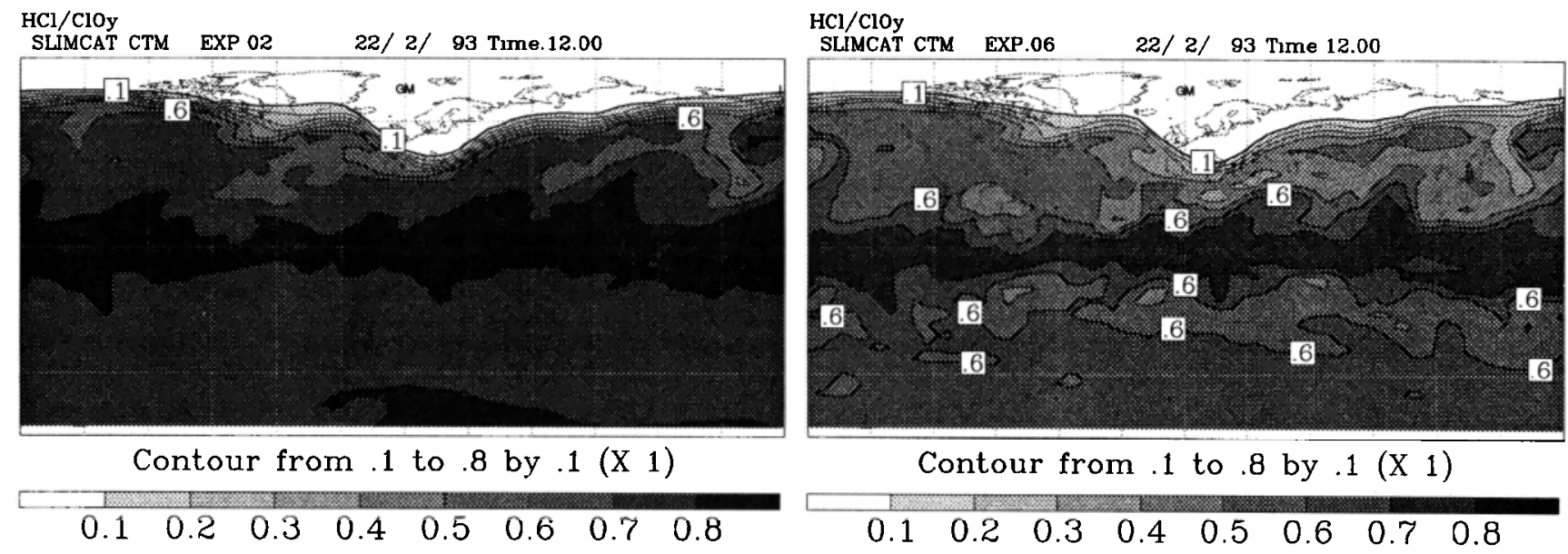

Figure 12. The $\mathrm{HCl} / \mathrm{ClO}_{y}$ ratio for simulations $\mathrm{SC} 2$ (background aerosol loading) and SC6 (enhanced aerosol loading) at $475 \mathrm{~K}$ on February 22, 1993.

lation with a volcanic aerosol loading (SC6). In agreement with the results presented earlier, the $\mathrm{HCl} / \mathrm{ClO}_{y}$ ratio is approximately between 0.4 and 0.6 throughout much of the mid-latitudes, as opposed to a value of between approximately 0.7 and 0.8 in simulations $\mathrm{SC} 1$ and $\mathrm{SC} 2$. For simulation $\mathrm{SC} 6$ the $\mathrm{HCl} / \mathrm{ClO}_{y}$ ratio is also low in the summer hemisphere, with values typically between 0.5 and 0.6 .

As discussed by Lary [this issue], it is unlikely that reaction (1b) proceeds. However, to investigate the possible importance of such a source of $\mathrm{HBr}$ simulations SC3 and SC4 were performed. A Comparison of experiments $\mathrm{SC} 1$ and $\mathrm{SC} 3$ showed the effect of including reaction (1b) with a $1 \%$ channel. Run SC3 has less polar ozone destruction than run SC1, the largest difference at the end of the run being $23 \mathrm{ppbv}$ (around 1\%, not shown) at the edge of the polar vortex. This is a larger effect on polar $\mathrm{O}_{3}$ than that from including the heterogeneous bromine reactions alone. The inclusion of reaction (1b) increased $\mathrm{HBr}$ in the polar vortex by around $2 \mathrm{pptv}$ (and by up to $4 \mathrm{pptv}$ at mid-latitudes) at the expense of $\mathrm{BrO}_{x}(\mathrm{BrO}+\mathrm{BrCl})$. This decrease in $\mathrm{BrO}$ reduces the ozone depletion.

When reaction (1b) is included in the model, the additional inclusion of the heterogeneous bromine reactions had a larger effect in the polar region. The increase in $\mathrm{HBr}$ due to reaction (1b) enables the heterogeneous reactions to recycle the additional $\mathrm{HBr}$ into $\mathrm{BrO}_{\mathrm{x}}$. The largest difference in accumulated $\mathrm{O}_{3}$ loss between runs SC4 and SC3 is $45 \mathrm{ppbv}$ (around $2 \%$ ) at the edge of the polar vortex in early March. The additional loss at mid-latitudes is around $20 \mathrm{ppbv}$, similar to but slightly less than the difference between runs SC2 and $\mathrm{SC} 1$ above. However, the additional depletion inside the polar vortex is now greater than that at mid-latitudes. This increase offsets the reduced ozone depletion due to the inclusion of reaction (1b) as the levels of $\mathrm{BrO}$ were similar between runs SC2 and SC4. Therefore, with only a $1 \%$ channel, reaction (1b) would have a significant effect, although there is no evidence for this channel from laboratory studies. A review of the kinetic measurements of (1b) is given by Lary [this issue]. Although the work of Mellouki et al. [1994] shows that reaction (1b) is in fact very slow, a comparison of $\mathrm{SC1}$ and SC2 with SC3 and SC4 (not shown) illustrated that an additional source of $\mathrm{HBr}$ would substantially affect our view of the partitioning of bromine species.

These simulations with the two-dimensional isentropic model for early 1993 have confirmed the results from the idealized box model runs above. The effect of the heterogeneous bromine reactions on PSCs is small. The most important heterogeneous bromine reaction is the hydrolysis of $\mathrm{BrONO}_{2}$. Under nonvolcanic conditions the reaction led to an additional $\mathrm{O}_{3}$ depletion at northern mid-latitudes of up to $18 \mathrm{ppbv}$ during the 2-month model run. With a volcanic aerosol loading the northern mid-latitude ozone depletion increased to $40 \mathrm{ppbv}$, while in the southern hemisphere, significant additional ozone depletion of over $130 \mathrm{ppbv}$ was produced along with changes to $\mathrm{ClO}$ and $\mathrm{HO}_{2}$.

\section{Summary}

Figure 13 summarizes the main gas phase and heterogeneous atmospheric photochemistry of bromine described in this paper and the companion paper Lary [this issue].

The effects of heterogeneous bromine reactions on sulfate aerosols and polar stratospheric clouds (PSCs) have been examined by using a range of photochemical models under a wide variety of conditions. The most important aerosol reactions were found to be the hydrolysis of $\mathrm{BrONO}_{2}$, and, for temperatures below $210 \mathrm{~K}$ and/or high water concentrations, the bulk phase reaction of $\mathrm{HOBr}$ with $\mathrm{HCl}$. These reactions take part in two catalytic ozone destruction cycles. Each cycle destroys three ozone molecules per cycle and enhance the $\mathrm{HO}_{x}, \mathrm{BrO}_{x}, \mathrm{ClO}_{x}$ and $\mathrm{HNO}_{3}$ concentrations while 


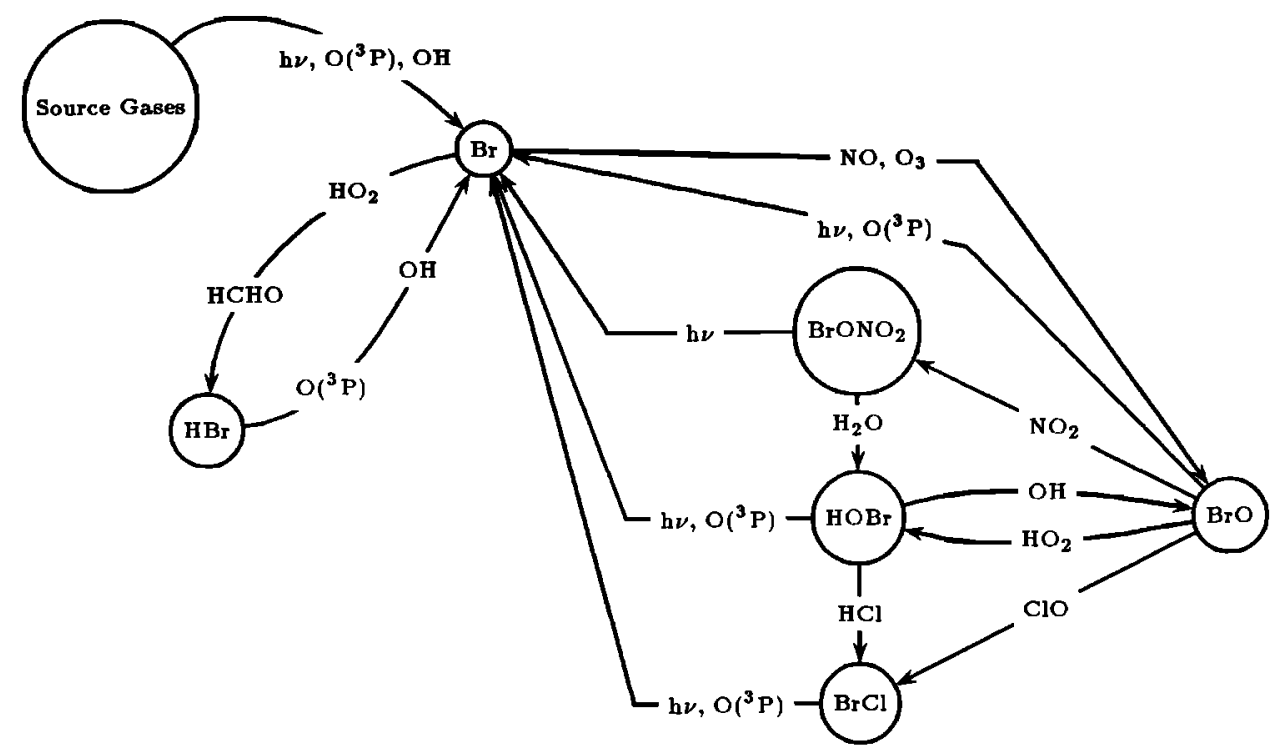

Figure 13. A schematic of atmospheric bromine photochemistry.

reducing the $\mathrm{HCl}$ and $\mathrm{NO}_{x}$ concentrations. The additional $\mathrm{ClO}_{x}$ and $\mathrm{BrO}_{x}$ activation that results enhances the effectiveness of the two gas phase $\mathrm{ClO} / \mathrm{BrO}$ cycles whose chain lengths can increase by an order of magnitude for enhanced aerosol loadings due to the hydrolysis of $\mathrm{BrONO}_{2}$. The catalytic $\mathrm{BrONO}_{2}$ hydrolysis cycle is shown to be important for lower stratosphere ozone loss at all latitudes, with a chain length of greater than $10^{3}$ for enhanced aerosol loadings. The enhancement in the $\mathrm{OH}$ concentration can substantially reduce the $\mathrm{HCl}$ lifetime and $\mathrm{HCl} / \mathrm{ClO}_{y}$ ratio in the lower stratosphere. The nighttime hydrolysis of $\mathrm{BrONO}_{2}$ leads to a nighttime enlancement of $\mathrm{HOBr}$, so that at dawn $\mathrm{HOBr}$ photolysis leads to a rapid rise in $\mathrm{OH}$ and $\mathrm{HO}_{2}$ as has recently been observed by Salawitch et al. [1994].

For a simulation of the winter of 1992-1993 on the $475 \mathrm{~K}$ isentropic surface constrained by ECMWF analyses, under nonvolcanic conditions the hydrolysis of $\mathrm{BrONO}_{2}$ led to an additional $\mathrm{O}_{3}$ depletion at northern mid-latitudes of up to $18 \mathrm{ppbv}$ during the 2-month model run. With a volcanic aerosol loading the northern mid-latitude ozone depletion increased to $40 \mathrm{ppbv}$, while in the summer of the southern hemisphere significant additional ozone depletion of over $130 \mathrm{ppbv}$ was produced along with changes to $\mathrm{ClO}$ and $\mathrm{HO}_{2}$.

On PSCs the most important heterogeneous bromine reactions are the mixed halogen reactions of $\mathrm{HCl}$ with $\mathrm{HOBr}$ and $\mathrm{BrONO}_{2}$ and $\mathrm{HBr}$ with $\mathrm{HOCl}$ and $\mathrm{ClONO}_{2}$.

Acknowledgments. The authors wish to thank J. A. Pyle for his support, R. A. Cox and J. Sessler for useful conversations and D. R. Hanson, A. R. Ravishankara, J. J. Orlando, J. B. Burkholder and M. Danilin for making their results available to us before publication. The Centre for Atmospheric Science is a joint initiative of the Depart- ment of Chemistry and the Department of Applied Mathematics and Theoretical Physics. This work forms part of the NERC U.K. Universities Global Atmospheric Modelling Programme. M. P. C. thanks Pascal Simon of CNRM, Toulouse, for help with SLIMCAT.

\section{References}

Abbatt, J. P. D., and M. J. Molina, The heterogeneous reaction of $\mathrm{HOCl}+\mathrm{HCl} \rightarrow \mathrm{Cl}_{2}+\mathrm{H}_{2} \mathrm{O}$ on ice and nitric-acid trihydrate: reaction probabilities and stratospheric implications, Geophys. Res. Lett., 19 (5), 461-464, 1992.

Abbatt, J. P. D., Heterogeneous reaction of $\mathrm{HOBr}$ with $\mathrm{HBr}$ and $\mathrm{HCl}$ on ice surfaces at $228 \mathrm{~K}$, Geophys. Res. Lett., 21 (8), 665-668, 1994.

Brimblecombe, P., and S.L. Clegg, The solubility and behaviour of Acid gases in the marine aerosol, J. Atmos. Chem., 7, 1-17, 1988.

Burkholder, J. B., A. R. Ravishankara and S. Solomon, UV visible and IR absorption cross-sections of $\mathrm{BrONO}_{2}, J$. Geophys. Res., 100 (D8), 16,793-16,800, 1995.

Chipperfield, M. P., D. Cariolle, P. Simon, R. Ramaroson and D. J. Lary, A three-dimensional modeling study of trace species in the Arctic lower stratosphere during winter 1989-1990, J. Geophys. Res., 98, 7199-7218, 1993.

Chipperfield, M. P., D. Cariolle, and P. Simon, A 3D chemical transport model study of chlorine activation during EASOE, Geophys. Res. Lett., 21, 1467-1470, 1994.

Chipperfield, M.P, A 3D Model comparison of PSC processing during the Arctic winters of $1991 / 92$ and 1992/93, Ann. Geophys., 12, 342-354, 1994.

Chipperfield, M.P, J. A. Pyle, C. E. Blom, N. Glatthor, M. Höpfner, T. Gulde, C. Piesch and P. Simon, The variability of $\mathrm{ClONO}_{2}$ and $\mathrm{HNO}_{3}$ in the Arctic polar vortex: Comparison of Transall MIPAS Measurements and 3D Model Results, J. Geophys. Res., 100, 9,115-9,129, 1995.

Cox, R. A., A. R. MacKenzie, R. H. Muller, T. Peter and P. J. Crutzen, Activation of stratospheric chlorine by reactions in liquid sulfuric acid, Geophys. Res. Lett., 21 (13), 1,439-1,442, 1994. 
Danilin, M. J., and J. C. McConnell, Stratospheric effects of bromine activation on/in sulfate aerosol, J. Geophys. Res., 100 (D6), 11,237-11,243, 1995.

DeMore, W. B., et al., Chemical kinetics and photochemical data for use in stratospheric modeling, Evaluation Number 10, Jet Propul. Lab., Pasedena, Calif., Publ. 94-26, 1994.

Fan, S.M., and D. J. Jacob, Surface ozone depletion in Arctic spring sustained by bromine reactions on aerosols, Nature, 359, 6395, 522-524, 1992.

Hanson, D., and K. Mauersberger, Laboratory studies of the nitric acid trihydrate: Implications for the south polar stratosphere, Geophys. Res. Lett., 15, 855-858, 1988.

Hanson, D.R., and A. R. Ravishankara, Investigation of the reactive and nonreactive processes involving $\mathrm{ClONO}_{2}$ and $\mathrm{HCl}$ on water and nitric-acid doped ice, J. Phys. Chem., $96(6), 2682-2691,1991$.

Hanson, D.R., and A. R. Ravishankara, Heterogeneous chemistry of $\mathrm{HBr}$ and HF, J. Phys. Chem., 96 (23), 94419446, 1992.

Hanson, D.R., and A. R. Ravishankara, Heterogeneous chemistry of bromine species in sulfuric acid under stratospheric conditions, Geophys. Res. Lett., 22 (4), 385-388, 1995.

Lary, D.J., Photochemical studies with a 3D model of the atmosphere, PhD. thesis, Cambridge Univ., Cambridge, England, 1991.

Lary, D.J., Gas Phase Atmospheric Bromine Photochemistry, J. Geophys. Res., this issue.

Lary, D. J., J. A. Pyle and G. Carver, A 3D model study of nitrogen-oxides in the stratosphere, Q.J.R. Meteorol. Soc., 120 (516), 453-482, 1994.

Lary, D.J., M. P. Chipperfield and R. Toumi, The potential impact of the reaction $\mathrm{OH}+\mathrm{ClO} \rightarrow \mathrm{HCl}+\mathrm{O}_{2}$ on polar ozone photochemistry, J. Atmos. Chem., 21 (1), 61-79, 1995.

Logan, J.A., Trends in the vertical distribution of ozone: An analysis of ozonesonde data, J. Geophys. Res., 99 (D12), 22,553-25,585, 1994.
McConnell, J.C., et al., Photochemical bromine production implicated in Arctic boundary-layer ozone depletion, $\mathrm{Na}$ ture, 355 (6356), 150-152, 1992.

Mellouki, A., R. K. Talukdar and C. J. Howard, Kinetics of the reactions of $\mathrm{HBr}$ with $\mathrm{O}_{3}$ and $\mathrm{HO}_{2}$ : the yield of $\mathrm{HBr}$ from $\mathrm{HO}_{2}+\mathrm{BrO}, J$. Geophys. Res., 99 (D11), 22,94922,954, 1994.

Orlando, J.J., and J. B. Burkholder, Gas phase UV/visible absorption spectra of $\mathrm{HOBr}$ and $\mathrm{Br}_{2} \mathrm{O}, J$. Phys. Chem., $99(4), 1,143-1,150,1995$.

Salawitch, R. J., et al., The diurnal-variation of hydrogen, nitrogen, and chlorine radicals: implications for the heterogeneous production of $\mathrm{HNO}_{2}$, Geophys. Res. Lett., 21 (23), 2,551-2,554, 1994.

Sessler, J., M. P. Chipperfield, J. A. Pyle and R. Toumi, Stratospheric $\mathrm{OClO}$ measurements as a poor quantitative indicator of chlorine activation, Geophys. Res. Lett., 22 (6), 687-690, 1995.

Toumi, R., BrO as a sink for dimethylsulfide in the marine atmosphere, Geophys. Res. Lett., 21 (2), 117-120, 1994.

WMO, Scientific Assessment of Stratospheric Ozone: 1991, WMO Global Ozone Research and Monitoring Project, Report 25, Geneva, Switzerland, 1992.

D. J. Lary, M.P. Chipperfield and T. Lenton, Centre for Atmospheric Science, Department of Chemistry, Cambridge University,Lensfield Road, Cambridge, CB2 1EW, U.K. (email:david@atm.cm.cam.ac.uk)

R. Toumi, Department of Physics, Imperial College, London, SW7 2BZ, U.K.

(Received March 9, 1995; revised June 28, 1995; accepted August 24, 1995.) 